\title{
Onze prelúdios para piano solo de Edmundo Villani-Côrtes: uma análise para a compreensão do potencial didático da obra para o desenvolvimento de habilidades técnico-interpretativas
}

Eleven preludes for solo piano by Edmundo Villani-Côrtes: an analysis to understand the pedagogical potential of these piano works for the development of technicalinterpretive skills

Luciana Fernandes Hamond ${ }^{1}$ Escola de Música Baden Powell Fundação de Apoio à Escola Técnica do Rio de Janeiro (Faetec-RJ) lucianahamond@gmail.com 


\section{Resumo}

Edmundo Villani-Côrtes (1930) é um dos compositores brasileiros de maior destaque da atualidade. Este artigo vem celebrar os noventa anos de nascimento do compositor por meio de um recorte da pesquisa de mestrado realizada há 15 anos. Dentre o acervo de mais de quatrocentas obras, encontram-se os onze prelúdios para piano solo compostos em diferentes épocas. O objetivo deste artigo foi realizar uma análise musical das obras seguindo as ideias de Schmalfeldt (2002) e Kochevitsky (1967) e identificar o potencial pedagógico dos prelúdios avaliando as habilidades técnico-interpretativas a serem desenvolvidas de acordo com os parâmetros de Uszler (1995). Além disso, uma revisão dos prelúdios foi realizada junto ao compositor. A pesquisa revelou a importância da obra como material didático e a sua posição no repertório de música brasileira para piano.

Palavras-chave: Edmundo Villani-Côrtes; Prelúdios; Música Contemporânea Brasileira; Pedagogia do Piano.

\section{Abstract}

Edmundo Villani-Côrtes (1930) is one of today's most prominent Brazilian composers. This article celebrates his ninetieth birthday through an excerpt from a research conducted 15 years ago. Among his over four hundred works, are the eleven preludes for solo piano composed at different times. The aim of this paper was to analyse the preludes following the ideas of Schmalfeldt (2002) and Kochevitsky (1967), and to identify the pedagogical potential by looking at the technical-interpretive skills to be developed in each one according to Uszler's parameters (1995). In addition, a review of the preludes was carried out with the composer. This research reveals the importance of Villani-Côrtes' piano preludes as pedagogical material and their place in the Brazilian piano music repertoire.

Keywords: Preludes; Edmundo Villani-Côrtes; Piano Pedagogy; Brazilian Contemporary Music.

Professora da Fundação de Apoio à Escola Técnica do Rio de Janeiro (Faetec-RJ), Brasil. Doutora pelo Institute of Education-UCL, Univer $\neg$ sity College London (Reino Unido), com Bolsa Doutorado Pleno no Exterior pela Capes. Realizou pós-doutorado na Universidade do Estado de Santa Catarina (Udesc), Brasil. 


\section{Como tudo começou}

O meu primeiro contato com a obra de Edmundo Villani-Côrtes ocorreu em 2001 no Rio de Janeiro, quando eu tinha ensaios regulares com a violinista Angélica Alves e a violoncelista Cláudia Grosso, e escolhíamos uma peça do repertório de música brasileira para a formação instrumental específica de trio para piano e cordas. A obra escolhida foi Cinco miniaturas brasileiras (1978), de Villani-Côrtes, a mais conhecida e tocada do compositor. Esta obra me encantou de imediato e me fez entrar em contato com o compositor numa época em que eu buscava escrever um projeto de mestrado. O projeto inicial era realizar um estudo comparativo entre as várias versões das Cinco miniaturas brasileiras de formação instrumental com piano, incluindo a versão original composta para flauta doce e piano. Atualmente há em torno de 15 versões desta obra, inclusive uma transcrição para piano solo. No entanto, no decorrer do curso, o colega Wendell Kettle, então aluno de Villani-Côrtes em São Paulo, entregou-me, a pedido do compositor, o seu álbum dos Dez prelúdios e cinco interlúdios para piano solo, editado por Ulisses de Castro pela Estúdio Dois Produções Culturais. Foi quando mudei o objeto de estudo do meu projeto de mestrado: os prelúdios para piano solo de Edmundo Villani-Côrtes.

Após a defesa do mestrado, os prelúdios e interlúdios, juntamente com as canções para piano solo, foram registrados em CD entre 2007 e 2008 no estúdio DRUM, em Laranjeiras, no Rio de Janeiro (RJ), com o engenheiro de som Alexandre Hang. Uma entrevista com Jose Schiller antecedendo o lançamento do CD foi concedida ao programa A grande música, sendo exibido pela Rede Brasil - antiga TVE - em 2009. O CD intitulado Luciana Hamond interpreta Edmundo Villani-Côrtes: prelúdios, interlúdios e canções para piano solo foi lançado em 2010 na ocasião de comemoração dos 80 anos no Centro Cultural São Paulo (SP) e no Centro de Integração Empresa-Escola (SP) em julho de 2010. No Rio de Janeiro, os lançamentos aconteceram na Livraria da Travessa (RJ), em maio de 2010, e no Theatro Municipal de Niterói, em julho de 2010 . $^{2}$ Todos os eventos contaram com a ilustre presença do compositor.

Em setembro de 2018, a convite de Thais Nicolau, ministrei um recital-palestra: Prelúdios e interlúdios de Edmundo Villani-Côrtes, como parte do II Festival de Música Contemporânea Brasileira Edino Krieger, realizado no auditório do Departamento de Música da Universidade do Estado de Santa Catarina (Udesc), em Florianópolis (SC). A receptividade e o interesse do público presente nesse recital-palestra me encorajaram a preparar este artigo, baseado na minha dissertação de mestrado (HAMOND, 2005), com atualizações de trabalhos acadêmicos subsequentes.

Em 2020, o compositor Edmundo Villani-Côrtes (1930) completa seus 90 anos. Em homenagem ao compositor, pretendo, por meio deste artigo, encorajar pianistas, professores e alunos de piano a conhecerem esse repertório pianístico que oferece um potencial pedagógico relevante na área de aprendizagem e ensino do piano de nível

O concerto realizado no Theatro Municipal de Niterói (RJ) foi filmado integralmente pela Rede Brasil e exibido para audiência nacional e está disponível no canal do YouTube da autora: https://www.youtube.com/user/lucianahamond/featured. 
intermediário, além de conhecerem a linguagem única do compositor que transita com excelência entre as músicas popular e erudita com seu estilo musical particular.

O potencial musical e pedagógico do repertório brasileiro para o ensino do piano de tem sido investigado por vários autores através de características composicionais, aspectos técnicos e didáticos, e avaliação do grau de dificuldade dessas obras (GANDELMAN; COHEN, 2006; GANDELMAN, 1997; BARANCOSKI, 2004; HARTMAN, 2017). No entanto, ainda há necessidade tanto da divulgação da literatura pianística por compositores brasileiros quanto da investigação sistemática de seus potenciais pedagógicos no ensino de piano.

O presente estudo tem como objetivo identificar e compreender o potencial didático dos onze prelúdios para piano de Edmundo Villani-Côrtes, incluindo o Prelúdio № 9 (1956) ao álbum Dez prelúdios e cinco interlúdios (2000), através de uma análise musical dessas peças (KOCHEVITSKY, 1967; SCHMALFELDT, 2002) e avaliação das habilidades técnico-interpretativas (USZLER, 1995). Neste artigo, o potencial didático envolve as habilidades técnicas e interpretativas possíveis de serem desenvolvidas a partir do estudo de uma obra. Desta forma, este artigo visa também contribuir para a divulgação da obra para o ensino e aprendizagem de piano.

\section{Sobre Edmundo Villani-Côrtes}

Edmundo Villani-Côrtes (1930) é um dos compositores brasileiros de maior destaque da atualidade. Compositor, maestro, pianista e arranjador, Villani-Côrtes tem sido requisitado por muitos músicos, produtores musicais e acadêmicos, obtendo reconhecimento no Brasil e no exterior. Vários músicos pesquisadores escreveram dissertações de mestrado (FREITAS, 2012; HAMOND, 2005; NETO, 2010; SANTOS, 2014; ZANON, 2005), teses de doutorado (ARAUJO FILHO, 2011; GIARDINI, 2013; NICOLAU, 2013; CARVALHO, 2016; MACHADO, 2017; RODRIGUES, 2014) e de pós-doutorado (BARONI, 2004), além de outras publicações, como artigos e entrevistas (MATOS, 2006; SANT'ANNA, 2006; SOBREIRO, 2016) para uma compreensão melhor de sua vida, seu estilo musical e suas obras. A formação musical de Villani-Côrtes é singular, visto suas experiências e vivências entre a música clássica e a música popular.

Nascido em Juiz de Fora (MG) em 8 de novembro de 1930, iniciou seus estudos musicais como autodidata com influências de seu pai, músico amador, flautista, e de seu irmão, ao violão, enquanto os observava em serestas. Aprendeu a tocar cavaquinho de ouvido, imitando os outros ao violão. Suas influências musicais vieram das programações de rádio e dos filmes musicais de uma época em que eram revividas as obras de Chopin, Liszt, Mozart, Puccini, Gershwin, dentre outros (LIMA, 1999). Tentava reproduzir no violão as músicas que ouvia no rádio, mas, quando essas tornaram-se difíceis, como por exemplo obras orquestrais, sentiu necessidade de iniciar seus estudos de piano.

Em 1969, Villani-Côrtes escreve a obra Sonata para violoncelo e piano, ${ }^{3}$ que foi o divisor de águas na sua carreira: "Foi uma espécie de libertação" (VILLANI-CÔRTES,

\footnotetext{
3 Mais tarde, essa sonata transformou-se no Concerto para violoncelo e orquestra (1976) e em 1996 ganhou uma versão para violoncelo de orquestra de câmara (VILLANI-CÔRTES, 2004a).
} 
2004a). O autor relembra suas impressões ao compor a peça: "Essa sonata eu quero escrever da seguinte maneira: se um dia chegar numa sala de concerto e tiver um violoncelo e um piano tocando, que som que eu quero ouvir? Que música eu queria ouvir?" (VILLANI-CÔRTES, 2004a). E compôs sem aceitar interferências.

O grito de liberdade do compositor é retratado no modo único de trilhar seu próprio caminho, usando até mesmo uma linguagem musical que, por diversas vezes, já foi utilizada por outros compositores. Certa vez, um aluno de composição comentou que estava lendo o romance Os sofrimentos do jovem Werther (1774), de Goethe (17491832). Villani-Côrtes se apropria da ideia do autor e comenta que uma passagem desta obra reflete justamente o seu pensamento:

Mais uma vez eu vou passar pelo mesmo caminho que eu mesmo já passei várias vezes. Caminho esse que já foi trilhado por muitas outras pessoas também, e que já passaram por esse mesmo caminho também. Mas eu vou passar por esse caminho como se fosse a primeira vez, de uma maneira tão autêntica que não é semelhante a nenhuma dessas outras. (VILLANI-CÔRTES, 2004a).

As implicações musicais deste trecho são assim interpretadas por Villani:

Se o caminho que você tem que seguir e que você escolheu, se o acorde que você escolheu é aquele, não interessa se foi tocado milhões de vezes. Aquele acorde, colocado naquela hora, foi colocado de maneira única e original, e foi colocado por você no momento que você achou que aquele acorde era o melhor. (VILLANI-CÔRTES, 2004a).

A obra de Villani-Côrtes reúne mais de 700 obras escritas, incluindo obras originais e versões transcritas pelo próprio compositor de suas obras para diversas formações instrumentais, como óperas, concertos, música de câmara, peças para canto e piano, vários duos, trios, quartetos. Dedicando-se à individualidade de cada instrumento, praticamente compôs para todos os instrumentos e piano solo. Possui mais de 40 CDs gravados em países como Japão, França, Inglaterra, Itália, Estados Unidos e Brasil. Sua obra mais conhecida, as Cinco miniaturas brasileiras, possui versões para várias formações instrumentais, para orquestra, para trio violino, violoncelo e piano, e duos. É muito comum acontecer de o autor transcrever algumas de suas obras para a formação instrumental por encomenda de músicos.

Edmundo Villani-Côrtes reside em São Paulo com a família desde a década de 1960. Sua esposa Efigênia é cantora lírica. Edmundo e Efigênia têm três filhos: a contrabaixista Gê Côrtes, a artista plástica Maitê Villani e o saxofonista, compositor e produtor musical Ed Côrtes. São sete netos, dentre eles João Côrtes, que é ator, cantor, pianista e baterista, e dois bisnetos de sua neta Carolina. Muitas de suas obras refletem temas de seu cotidiano, como Borulóides, que foi uma obra composta baseada em lendas infantis que ele mesmo criou para brincar com seus filhos. Seus filhos, netos, neta e bisnetos ganharam composições com seus nomes, como, por exemplo: O orelha (1983) e Balada dos 15 minutos (1993) para seu filho produtor musical e saxofonista Ed Côrtes; Rue Ramponeau (2007), Ânfora (2011) e Beiráceas (1978) para sua filha artista plástica 
Maitê; Praeludius Onnibus (1979), Choron (1981), Concerto para contrabaixo e orquestra (1996-2001), dedicado à sua filha contrabaixista Gê Côrtes. Várias obras foram compostas homenageando o nascimento de seus netos: o Choro do João (1995); O Gabriel chegou (1997); a Sonata № 1 (1994), dedicada aos netos gêmeos Renato e Giovanni; Canção de Carolina (1990); Francisco no choro (2006); Acalanto (2013), dedicada ao neto Guilherme; e Salve Salve Daniel (2012) e o Choro do Gugu (2017), dedicada aos seus bisnetos, filhos de sua neta Carolina. A canção Você (1958) foi dedicada à sua esposa Efigênia.

\section{Obra para piano solo}

A produção de Villani-Côrtes para piano solo (vide Anexo) ${ }^{4}$ abrange uma variada gama de gêneros, correspondendo a cerca de um quarto da produção musical total do compositor. O compositor utiliza gêneros tradicionais, como o prelúdio, o estudo, a suíte, o tema com variações, a sonata, a sonatina, a tocata, o adágio e o interlúdio, além de gêneros musicais brasileiros, como o choro, a toada, a canção, a cantiga de ninar, e do gênero jazz, como o boogie e a balada.

As peças para piano foram compostas em diferentes épocas e englobam peças originalmente compostas para piano solo e as versões de obras compostas para outras formações transcritas para piano solo, pelo próprio compositor. Dentre as peças escritas para piano estão os oito prelúdios (1949-1956), suas primeiras composições. Dentre as versões transcritas para piano estão as Cinco miniaturas brasileiras (1978), original para flauta doce e piano (1978). Algumas canções também foram transcritas pelo compositor, que as reuniu num álbum intitulado Canções para piano solo: Papagaio azul (1966), Valsinha de roda (1979), Canção de Carolina (1990), Alma da natureza (1991), Casulo (1991), Rua Aurora (1993), Balada dos 15 minutos (1993) e Choro das madrugas (1999).

A produção para piano solo inclui outros títulos que nos remetem à música popular, principalmente de influência jazzística, como é o caso de Pedrinho's boogie (1994), feita especialmente para a gravação do CD de seu amigo pianista Pedrinho Mattar.

O choro é um gênero muito presente na sua produção musical para piano solo, aparecendo num dos quatro movimentos da Série Brasileira opus 8 (1957) - Prelúdio, Dança, Movimento em 3/4, Chôro em forma de rondó. Villani-Côrtes também compôs dez choros e os reuniu no Álbum de chôros para piano solo ${ }^{5}$ (1999): Os chorões da Paulicéia, O orelha, Chôro do João, O Gabriel chegou, Chôro urbano, Chôro miniatura, Chôro das madrugas, Chôro patético, Canhoto também tem vez e Pretensioso.

As experimentações de efeitos sonoros e formas incomuns de tocar, incluindo o uso do antebraço ou até mesmo da testa, são encontradas em Timbres № 1 e $N$ o 2 (1977), compostas durante o período em que estudou com Koellreutter. Ao tocar os

\footnotetext{
$4 \quad$ O Anexo apresenta a lista da produção musical para piano (piano solo, piano a quatro mãos e para dois pianos), incluindo obras para órgão, em ordem cronológica. A lista da obra para piano foi atualizada por meio de conversa ao telefone com o compositor em 31 de março de 2020. 
Timbres № 1 e № 2 (1977) na presença do compositor, Villani-Côrtes comentou que imaginou a peça como se fosse um fundo musical de um filme de terror, e foi abordada a importância do lado cênico na interpretação, pois o intérprete deve retratar o clima de mistério durante a execução da obra: "A pessoa tem que tocar isso pensando sempre em criar uma expectativa... expectativa baseada em contrastes, em efeitos de timbres do instrumento e rítmicos inesperados" (VILLANI-CÔRTES, 2003).

As obras de Villani-Côrtes para o instrumento apresentam um repertório que abrange o estudo pianístico atendendo a diversos aspectos para o desenvolvimento das habilidades técnico-interpretativas ao piano: desde peças simples àquelas de maior virtuosidade, formando um repertório de música brasileira vasto e diversificado, enriquecendo as possibilidades de escolha para os pianistas.

\section{A relação entre análise e os aspectos técnico-interpretativos}

Ao iniciar o estudo dos prelúdios, pude constatar, na partitura de alguns deles, a ausência de marcação metronômica, poucas indicações de dinâmica, entre outras informações que necessitavam de esclarecimentos. Algumas questões foram surgindo: quais seriam os subsídios extramusicais que o compositor pode nos oferecer para que possamos esclarecer aspectos interpretativos dos prelúdios? Os prelúdios foram compostos com finalidade didática? Quais as contribuições que essa obra, como repertório, pode oferecer e/ou representar para um pianista, ou para um aluno do instrumento, em relação ao desenvolvimento de suas habilidades técnico-interpretativas? Este artigo, portanto, propõe-se a elucidar as questões acima relacionadas.

O contato com o compositor por meio de entrevistas e de encontros para apresentar as interpretações de suas obras, juntamente com um estudo que relacionasse a análise musical e a avaliação de seu potencial didático, com foco nos aspectos técnico-interpretativos, foi crucial para a compreensão do lugar dessa obra dentro do repertório de música brasileira na área da pedagogia do piano.

A análise musical tem sido considerada uma importante ferramenta para uma maior consciência do pianista, seja professor, seja aluno, em relação aos aspectos técnicos- pianísticos envolvidos para a execução de uma obra (KOCHEVITSKY, 1967; SCHMALFELDT apud CAVAZOTTI; GANDELMANN, 2002). A análise prévia de uma obra musical promove a compreensão clara de todos os seus elementos (KOCHEVITSKY, 1967, p.50). Alinhada com essa ideia, Schmalfeldt (apud CAVAZOTTI; GANDELMANN, 2002) afirma que começa a pensar analiticamente sobre uma peça iniciando os trabalhos técnico e analítico concomitantemente, duas atividades consideradas por ela inseparáveis. Dessa forma, a análise musical é uma ferramenta para compreender:

A interação de todas as dimensões musicais - ou seja, motivo, ideia, frase, progressão harmônica, cadência, ritmo, compasso, textura, condução de vozes, dinâmica, instrumentação e plano tonal geral. (SCHMALFELDT apud CAVAZOTTI; GANDELMANN, 2002, p.58, grifo do autor). 
Kochevitsky complementa a proposta acima ao afirmar:

Antes de tocar uma obra, ele [o intérprete] deve se familiarizar com a sua forma, estruturas harmônicas e polifônicas, relações métrico-rítmicas, desenho melódico, fraseado, articulação, qualidade da sonoridade desejada e gradações de dinâmica. Ele tem que tratar de questões técnicas - posições e movimentos de seu aparato motor, tipos de toque e dedilhado apropriado. (KOCHEVITSKY, 1967, p.50, tradução minha). ${ }^{6}$

Através da familiarização com esses elementos estruturais, o intérprete pode tocar uma peça conscientemente - o que significa que o pianista vai elaborar uma interpretação através dos enfoques adquiridos por meio da análise musical (RINK, 2007, p.25). A partir do momento que o intérprete possui uma imagem sonora ${ }^{7}$ da obra, fundamentada analiticamente, pode fazer, então, escolhas sobre o dedilhado e decidir também sobre pedalização e articulação (SCHMALFELDT apud CAVAZOTTI; GANDELMANN, 2002).

Ao iniciar o estudo de uma obra, o intérprete busca a execução mais fiel possível às anotações do autor, ao seu estilo e às tendências de sua época. Durante anos de estudo do repertório, o intérprete vai desenvolvendo, através de sua vivência musical, familiaridade e conhecimento sobre os mais diversos estilos: Barroco, Clássico, Romântico e Moderno. Ao executar uma obra de um autor contemporâneo, em que ainda estão sendo estabelecidas tradições interpretativas, como é o caso da obra de Villani-Côrtes, toda a bagagem estilística trazida pelo instrumentista será válida para a sua interpretação. O conhecimento prévio de repertório, no âmbito da interpretação musical e de suas convenções, favorece uma boa compreensão e, consequentemente, terá um impacto positivo na performance de determinada obra.

A análise musical de uma obra tem um impacto na compreensão da obra e, consequentemente, na execução musical. No entanto, o preparo técnico de um instrumentista está intimamente ligado à sua capacidade de responder musicalmente. Por sua vez, o instrumentista idealiza uma performance através de sua compreensão da obra e de seu preparo técnico, onde a proximidade entre a interpretação artística desejada e a execução musical realizada demonstra o nível de compreensão da obra. Kochevitsky (1967) ressalta sobre a interdependência dos aspectos interpretativos e técnico:

Técnica é a interdependência entre nosso aparato de tocar, nossa vontade e nossas intenções artísticas. Na técnica perfeita, a vontade e o movimento aparecem como uma coisa só. Técnica é o ajuste às intenções artísticas e normalmente é somente o meio para atingir uma meta definida. (KOCHEVITSKY, 1967, p.13-14, tradução minha). ${ }^{8}$

\footnotetext{
$6 \quad$ Original: "Before playing a composition he has to become familiar with its form, harmonic and polyphonic structure, metrical-rhythmic relationships, melodic design, phrasing, articulation, quality of desired sonority and dynamic shading. He has to consider technical questions positions and movements of his playing apparatus, kind of touch and appropriate fingering".

7 Sound image. Consideramos imagem sonora de Schmalfeldt como sinônimo de imagem acústica de Hofmann. "A completa imagem acústica da música deve estar alojada na mente, antes de ser expressada pelas mãos. Então tocar é simplesmente a expressão manual de algo [que o pianista] sabe" (HOFMANN apud KOCHEVITSKY, 1967, p.50, grifo do autor). Do original: "The full acoustic picture of the music must be lodged in the mind, before it can be expressed through the hands. Then the "playing is simply the manual expression of something [a pianist] knows".

$8 \quad$ Original: "Technique is the interdependence of our playing apparatus with our will and our artistic intentions. In the perfect technique the will and the movement appears as one. Technique is the adjustment to artistic intentions and normally is only the means to achieve a definite goal".
} 
Perfeição técnica não deveria ser medida através do domínio do pianista sobre um ou outro tipo de técnica, mas através da correspondência entre suas intenções artísticas e os meios de sua realização. (KOCHEVITSKY, 1967, p.37, tradução minha). ${ }^{9}$

Desta forma, quanto maior o nível técnico, mais fiel a performance será das intenções artísticas e musicais que o pianista imaginou. A seguir, serão abordadas as habilidades técnico-interpretativas a serem desenvolvidas no estudo de repertório pianístico de nível intermediário.

\section{O potencial pedagógico de nível intermediário}

A atividade de professor de piano requer a prudente atitude de escolher, junto com o aluno, o repertório, que deve ser adequado para o desenvolvimento individual técnico-interpretativo de cada aluno pianista. Autores da área da pedagogia do piano (BASTIEN, 1973; HOBSON, 1996; USZLER, 1995) debruçaram-se em pesquisar e avaliar as habilidades a serem desenvolvidas no nível intermediário do repertório e do estudo pianístico.

Bastien (1973) apresenta seis áreas para o desenvolvimento da técnica do aluno intermediário: escalas, arpejos, acordes, notas duplas, trinados e estudos técnicos especializados. Hobson (1996) indica uso de repertório para o desenvolvimento de movimento lateral do punho, uso do peso, cantabile, articulações diversas (legato, staccato, portato), staccato de mão, staccato de dedo para passagens rápidas, independência dos dedos, notas duplas (em terças e outros intervalos), além do uso do pedal sustain (direito) e una corda (esquerdo).

Uszler (1995) considera as seguintes habilidades técnicas a serem desenvolvidas por alunos do nível intermediário: legato em passagem extensa e em notas duplas; vários tipos de staccato (pulso, braço, dedo); substituição de dedo; escalas e arpejos em tonalidades maiores e menores; ornamentação; abertura de mão na extensão de uma oitava; oitavas; independência de mãos e dentro de uma só mão; acordes de quatro sons; refinamento em estilos de acompanhamento; mudanças rápidas de registro e de textura, mobilidade; sentido de dinâmica, cor e caráter; pedalização sincopada, rítmica e uso do pedal una corda; desenvolvimento de velocidade, força, resistência e coerência (USZLER, 1995, p.214-215).

Esta autora defende um trabalho integrado com o repertório e aponta para três áreas do desenvolvimento de habilidades técnico-interpretativas: independência, mobilidade, e controle da sonoridade. Cada categoria é organizada em subáreas, como podemos observar na Tab. 1. 


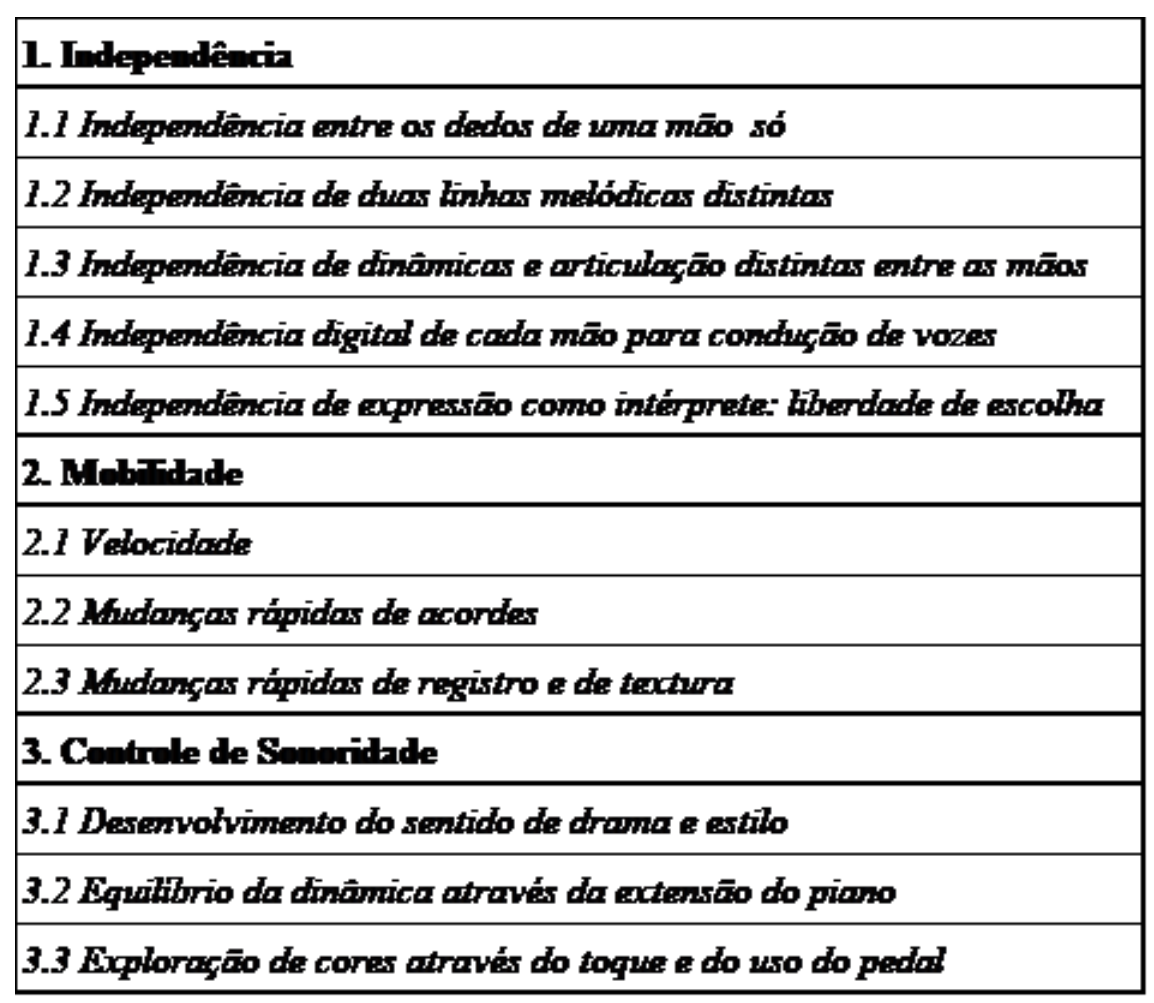

Tab. 1: Áreas e subáreas de desenvolvimento técnico-interpretativo. Fonte: Uzsler (1995).10

A primeira categoria (USZLER, 1995), independência, se refere à consciência do aluno em distinguir e apreciar a independência, ouvindo e tocando uma peça; é organizada em cinco subáreas. A primeira subárea avalia o que apenas uma das mãos é capaz de fazer - seja tocar uma melodia simples, seja tocar uma melodia com acompanhamento, dosando o peso da mão em diferentes registros do piano. A segunda subárea desenvolve a consciência da textura a duas vozes através do enfoque da independência de dinâmica, ritmo, articulação, e/ou a combinação de todos esses elementos. A terceira subárea trabalha o equilíbrio cuidadoso de dinâmica e de articulação entre as mãos, especialmente em peças homofônicas. A quarta subárea desenvolve a consciência da distribuição do peso na mão através de toque timbrado de uma linha melódica. Finalmente, a quinta subárea envolve a tomada de decisões técnico-interpretativas acerca da obra executada pelo intérprete, através do uso de improvisação, ornamentação, pedalização, condução da agógica, entre outros.

A segunda categoria (USZLER, 1995), mobilidade, inclui tudo o que lida com ajustes rápidos do corpo, mãos e dedos; é organizada em três subáreas. A primeira subárea envolve regular a velocidade com consciência e controle em passagens que exijam agilidade, como arpejos, padrões escalares, escalas cromáticas e ornamentos. A segunda subárea envolve ajustes cinestésicos múltiplos, requerendo uma constante mudança de configuração da mão, como, por exemplo, através de mudanças rápidas de acordes. A terceira subárea desenvolve o equilíbrio de força e de peso em peças que combinam diferentes registros e texturas a fim de dar dramaticidade ou humor às obras.

$10 \quad$ Original: "1. Independence: Independence of the single hand, Playing two independent lines, Independence of dynamics and articulation, Independence within the hand, Independence of expression: freedom to make choices; 2. Mobility: Velocity, Quick chord changes, Quick changes of register and texture; 3. Tonal control: Developing a sense of drama and style, Balancing dynamics throughout the keyboard range". 
A terceira categoria (USZLER, 1995), controle de sonoridade, aborda a habilidade de tocar diferentes tipos de som, de explorar o amplo espectro de coloridos sonoros "através do estímulo das capacidades imaginativas e auditivas do aluno"11 (USZLER, 1995, p.222), e estudar os meios para alcançá-lo; é organizada em três subáreas. A primeira subárea envolve o trabalho do aluno ser capaz de identificar, principalmente através do estímulo auditivo, alguns elementos musicais inerentemente dramáticos, como, por exemplo, passagens em movimento contrário, uso de extremidades do teclado, propulsão rítmica intensa, modulações em tonalidades inesperadas, entre outros. A segunda subárea requer um treinamento auditivo e do aparato motor a fim de se obter, por exemplo, um toque suave ou um som fundo de tecla. Finalmente, a terceira subárea visa estimular e desenvolver o ouvido e a imaginação do aluno sobre a construção de diferentes sonoridades através de toques e sobre a utilização do pedal como um meio de alcançar um colorido sonoro. Desta forma, o trabalho de Uszler (1995) foi tomado como referência para analisar o potencial didático para o desenvolvimento de habilidades técnico-interpretativas de cada prelúdio de Edmundo Villani-Côrtes.

\title{
Os prelúdios para piano solo de E. Villani-Côrtes
}

\begin{abstract}
Os prelúdios foram os primeiros passos que dei para iniciar uma longa caminhada. Para onde? Para a arte, para as estrelas, para o infinito... (VILLANI-CÔRTES, 2000, p.5).
\end{abstract}

São onze os prelúdios de Villani-Côrtes compostos em diferentes épocas. Dez prelúdios estão inseridos no referido álbum publicado em 2000 pela Estúdio Dois Produções Culturais; ${ }^{12}$ e o Prelúdio № 9, com a data de composição de 1956, que foi publicado separadamente pela Irmãos Vitale (São Paulo) em 1977. A peça não foi publicada no álbum pois a editora impossibilitou sua inclusão ao exigir do compositor um valor absurdamente alto pelos direitos de reedição. Para completar a série de dez prelúdios, Villani-Côrtes compôs então o Prelúdio op. 2 № 9. Em contrapartida, os Prelúdios № 3 e № 4 foram publicados anteriormente pela extinta Cultura Musical (São Paulo) em 1980 e em 1981, respectivamente, e puderam ser reeditados e inseridos no álbum de 2000 devido à falência desta editora, o que propiciou o retorno dos direitos ao compositor sobre essas peças. Por meio do contato com o compositor, foi possível resgatar o Prelúdio № 9, e assim completar a série dos onze prelúdios. A partir daqui será adotada a denominação Prelúdio № 9 (1956) para distingui-lo do Prelúdio op.2 № 9 no presente artigo.

Através dos manuscritos das partituras, podemos verificar que o autor reuniu e organizou seus primeiros oito prelúdios em 1957, intitulando o grupo de peças com as seguintes inscrições: 8 Prelúdios, Juiz de Fora, 3-5-957 (vide HAMOND, 2005). O compo-

\footnotetext{
11 Original: "[...] by stimulating the imaginative and listening capacities of the student rather than by isolating and explaining specific techniques of tonal production".

12 Uma nova edição foi realizada pela Musica Brasilis através do site https://musicabrasilis.org.br/.
} 
sitor afirma que, genericamente, esses prelúdios foram compostos entre 1949 e $1957 .{ }^{13}$ Os prelúdios do álbum estão numerados consecutivamente de um a dez, com exceção do Prelúdio op.2 № 9. Apenas os Prelúdios № 2 e op. $2 N^{\circ} 9$ apresentam indicação das datas de composição na partitura: 1949 e 16/7/1998, respectivamente. O Prelúdio $N^{\circ}$ 10 corresponde à versão para piano solo do primeiro movimento de Cinco miniaturas brasileiras (1978), e, apesar de não estar datado, foi escrito na mesma época do Prelúdio op. 2 № 9, para a ocasião do lançamento do álbum. ${ }^{14}$

Ao entrevistar o autor, comentei que os prelúdios do álbum mostravam uma certa coerência na sequência em que foram colocados na publicação, ou seja, como se estivessem encadeados através de relações intervalares de segundas maiores, terças menores, quintas justas e, até mesmo, por ligação entre tonalidades relativas ou homônimas, conferindo uma certa continuidade, apesar de estarem dispostos valorizando contrastes no caráter e na sonoridade. O compositor afirmou que alterou a ordem original dos primeiros oito prelúdios compostos na década de 1950 para o lançamento do álbum de 2000 (VILLANI-CÔRTES, 2004a). Quatro dos oito primeiros prelúdios tiveram a sua numeração modificada para a publicação do álbum, seguindo uma sequência imaginada pelo compositor. A mudança da numeração com a minutagem de cada peça pode ser observada nas Tab. 2 e 3 a seguir, com exceção dos Prelúdios op. 2 № 9 e № 10, pois não tiveram sua ordem alterada, sendo apenas acrescidos à série dos primeiros oito prelúdios.

\begin{tabular}{|c|c|c|c|c|c|c|c|c|}
\hline $\begin{array}{l}\text { Numeracão original do } \\
\text { maniscrito }\end{array}$ & $\mathbf{1}$ & 2 & 3 & 4 & 5 & 6 & 7 & $\mathbf{8}$ \\
\hline Tonatidade & $\begin{array}{l}\text { Dó } \\
\text { mainar }\end{array}$ & Fá & $\begin{array}{c}\text { Ré } \\
\text { menor }\end{array}$ & $\begin{array}{l}\text { Sol } \\
\text { mainer }\end{array}$ & $\begin{array}{l}\text { Fá } \\
\text { maior }\end{array}$ & $\begin{array}{l}\text { Mib } \\
\text { maing }\end{array}$ & $\begin{array}{l}\text { Sol } \\
\text { maingr }\end{array}$ & Dó \\
\hline Duracão (mintus) & $1^{2} 45^{\prime \prime}$ & $130^{\circ}$ & $1^{2} 30^{\circ}$ & $1^{\prime} 10^{\circ}$ & $2^{2} 40^{-}$ & $1^{2} 30^{\circ}$ & $1^{2} 35^{\prime \prime}$ & $1^{2} 30^{\circ}$ \\
\hline
\end{tabular}

Tab. 2: Numeração original dos oito primeiros prelúdios do manuscrito.

\begin{tabular}{|c|c|c|c|c|c|c|c|c|}
\hline Numeração da ediç̃õo de 2000 & 1 & 2 & 3 & 4 & 5 & 6 & 7 & 8 \\
\hline $\begin{array}{c}\text { Numeração original do } \\
\text { manuscrito }\end{array}$ & 1 & 6 & 3 & 2 & 4 & 5 & 7 & 8 \\
\hline Tonatidade & $\begin{array}{c}\text { Dó } \\
\text { mainx }\end{array}$ & $\begin{array}{l}\text { Mib } \\
\text { maing }\end{array}$ & $\begin{array}{c}\text { Ré } \\
\text { menor }\end{array}$ & $\begin{array}{l}\text { Fá } \\
\text { maingr }\end{array}$ & $\begin{array}{l}\text { Sol } \\
\text { mainer }\end{array}$ & $\underset{\text { mainar }}{\text { Fá }}$ & Sol & $\begin{array}{c}\text { Dó } \\
\text { menor }\end{array}$ \\
\hline Dração (minitns) & $1^{2} 45^{\prime}$ & $1^{3} 30^{\circ}$ & $1^{2} 30^{\circ}$ & $1^{\prime} 10^{\circ}$ & $2^{2} \mathbf{4 0}$ & $1^{2} 30^{\circ}$ & $1^{3} 35^{\prime \prime}$ & $1^{2} 30^{\circ}$ \\
\hline
\end{tabular}

Tab. 3: Modificação da ordem da numeração dos prelúdios para a publicação da edição de 2000.

Nos seus onze prelúdios, sua escrita é clara e concisa, com um nível de detalhamento que constantemente oferece ao pianista oportunidades de decisões interpreta-

\footnotetext{
13 Em depoimento à autora, ao telefone, no dia 16 de julho de 2005, não registrado.

14 Em depoimento do compositor, em outubro de 2004, não registrado.
} 
tivas, seja através de elementos indicados na partitura que apresentam diversas possibilidades de execução, tais como fraseado e sonoridade, seja através de elementos não escritos. Os prelúdios são textos musicais que refletem o pensamento do compositor e que deixam transparecer o conhecimento e a vivência musical do autor como pianista. As peças são muito bem escritas para o piano, o que torna a obra idiomática para o instrumento. Alguns aspectos da escrita musical do compositor serão abordados a seguir a fim de realizar uma avaliação do equilíbrio entre a precisão da notação do compositor versus a liberdade por parte do intérprete.

Quanto aos registros do piano, Villani-Côrtes explora quase toda a extensão do teclado do piano, usando desde o extremo agudo (Dó 6) ao extremo grave (Dó -1), para efeitos sonoros e finalizações, porém a região mais explorada está no âmbito do Dó 1 ao Dó 5.

Em relação à variedade de dinâmica, a maior parte dos prelúdios tem indicação detalhada de dinâmica, variando um espectro de uma a cinco gradações, entre ppp a ff, o que propicia uma ampla exploração de sonoridades (Tab. 4). O maior número de indicações de dinâmicas diferentes encontra-se nos Prelúdios № 4, № 8 e № 9 (1956), enquanto nos Prelúdios № 6 e № 10 a dinâmica oscila entre apenas dois níveis. Apesar da intensidade máxima utilizada em quatro prelúdios ser $f$ ou ff e em outros sete ser $p$ ou $m f$, os prelúdios apresentam uma dinâmica predominantemente em $p$ e pp, nos convidando a expressar uma sonoridade mais intimista.

\begin{tabular}{|c|c|c|}
\hline Prelífios & $\begin{array}{c}\text { Gradaçốes de drâmica com frequância e constância } \\
\text { em nímero de compassos (c). }\end{array}$ & $\begin{array}{c}\text { Nümero de } \\
\text { gradacôes de } \\
\text { drâmica }\end{array}$ \\
\hline$N^{2} 1$ & $p p p(1 c) ; p p(18 c) ; p(34 c) ; m f(15 c)$ & 4 \\
\hline$N^{a} 2$ & $P P P(1 \mathrm{c}) ; P P(3 \mathrm{c}) ; p(18 \mathrm{c}) ; m f(5 \mathrm{c})$ & 4 \\
\hline$N^{2} 3$ & $p p(1) ; p(26 c) ; f(2 c)$ & 3 \\
\hline$N^{2} 4$ & $p p p(1 \mathrm{c}) ; p P(30 \mathrm{c}) ; p(31 \mathrm{c}), m f(4 \mathrm{c}) ; f(1 \mathrm{c})$ & 5 \\
\hline$N^{2} 5$ & $p p p(1 c), p p(1 c){ }_{5} p(34 c), m f(1 c)$ & 4 \\
\hline$N^{a} 6$ & $p p(2 c) ; p(85 c)$ & 2 \\
\hline$N^{2} 7$ & $p(14 \mathrm{c}) ; m f(1 \mathrm{c}), f(3 \mathrm{c}) ; f(\mathrm{lc})$ & 4 \\
\hline$N^{2} 8$ & $p p p(1 \mathrm{c}) ; p p(1 \mathrm{c}) ; p(24 \mathrm{c}) ; f(4 \mathrm{c}) ; f(2 \mathrm{c})$ & 5 \\
\hline$N^{2} 9(1956)$ & $P p(3 \mathrm{c}) ; p(17 \mathrm{c}) ; \mathrm{wf}(2 \mathrm{c}) ; f(1 \mathrm{c}) ; f(\mathrm{c})$ & 5 \\
\hline Op. $2 N^{n} g$ & $p p p(2 c), p p(1 c) ; p(26 c), m f(4 c)$ & 4 \\
\hline$N^{m} 10$ & $p p(1 c) ; p(63 c)$ & 2 \\
\hline
\end{tabular}

Tab. 4: Gradações de dinâmica com frequência e constância em número de compassos para cada prelúdio.

A indicação de dedilhado é um elemento ausente em seus prelúdios. Como são bem escritos para o instrumento, o intérprete tem a liberdade de escolha, levando em consideração o fraseado imaginado para a peça, optando sempre por um dedilhado que lhe seja confortável e esteja de acordo com suas características físicas e seu desenvolvimento técnico. 
Em relação à variedade de toques, encontramos as indicações de legato, de non legato, de pequenas ligaduras de articulação e de nota com tenuta. É surpreendente notar que não há nenhuma indicação de staccato. A predileção de Villani-Côrtes pelo toque legato em suas obras é evidente. Entretanto, o intérprete deve explorar a riqueza sonora dos prelúdios levando em consideração o caráter da peça, as indicações do compositor, além da experiência e do conhecimento musicais prévios do intérprete. Por exemplo, no Prelúdio op.2 № 9, o toque firme e presente é subentendido através da indicação do caráter rítmico e das articulações das notas, apesar da dinâmica em $p$. Já no Prelúdio № 6, o toque velado e claro pode ser percebido a partir da presença de ligaduras de prolongamento e do caráter fluente, ambos indicados. Interessante citar o sfz encontrado no final do Prelúdio $N$ № 8 como a única ocorrência de acento nesta obra.

As indicações de andamento, marcação metronômica (M.M.), caráter, fórmula de compasso (F.C.) e variação de agógica são ilustradas na Tab. 5. Sete dos onze prelúdios apresentam indicação de andamento, oito de M.M., sendo que seis deles possuem as duas informações. A mudança de fórmula de compasso ocorre com frequência em três dos onze prelúdios. Ao contrário dos outros aspectos, a agógica é bem explorada em todos os prelúdios, exceto no Prelúdio No 9 (1956), no qual apenas poco rallentando e rallentando são designados. As indicações adicionais de caráter nos trechos intermediários da peça estão presentes com uma certa constância nos termos ingenuamente, perdendo-se, entre outros. As anotações de agógica são muito claras, auxiliando o pianista na sua interpretação, através de: retendo, apressando um pouco, affretando [sic], entre outros.

Não há nenhuma indicação de pedal nos Prelúdios, seja ele o pedal direito (sustain), o esquerdo (una corda) ou, ainda, o tonal. A pedalização faz parte das decisões interpretativas do intérprete, pois o compositor, ao não indicar o uso de pedais, oferece total liberdade de escolha ao pianista. Faz-se necessário o seu uso cuidadoso, sem excessos, para favorecer o entendimento sonoro de mudanças harmônicas e a precisão rítmica. $O$ uso do pedal pode ser subentendido quando a peça apresenta algumas características, como, por exemplo: sustentar notas longas ou notas pedal, como ocorre nos Prelúdios № 2 e № 9 (1956); propiciar a ressonância de notas que formam a harmonia, como acontece nos Prelúdios № 6, № 7 e $N$ ㅇ 8; favorecer o caráter das peças, nos casos de Cantabile no Prelúdio No 4, como um regato, fluente no Prelúdio $N$ ㅇ 6, etéreo no Prelúdio № 10 e Calmo, bem ligado no Prelúdio № 5. 


\begin{tabular}{|c|c|c|c|c|c|}
\hline Pnelistio & Andamento & MM & Caríter & Fómula de compasso & Variag̃ão de Agógica \\
\hline$N^{n} 1$ & Moderato & $\theta=128$ & - & 3/4 & $\begin{array}{l}\text { poco rall, a tempo, poco ofret, poco rall, Tempo I, } \\
\text { poco piü, rall, a tempo, poco piu, rall, Tempo I }\end{array}$ \\
\hline$N^{2} 2(1949)$ & Moderato & $\theta=96$ & - & 4/4 & poco rall, rall, Tempo $I$, roll até ofum, perdendo-se \\
\hline$N^{*} 3$ & Lento & $\theta=66$ & Expressivo / cantabile & $2 / 4$ & poco roll, a tempo, affretando, roll, a tempo, rall \\
\hline$N^{2} 4$ & - & - & Cantabile (com tranquitidade) & $2 / 4,5 / 4,3 / 4,2 / 4$ & roll, a tempo, rall, a tempo, a tempo, menos. \\
\hline$N^{2} 5$ & - & $\theta=66$ & Cadmo, bem ligado & $3 / 4$ & $\begin{array}{l}\text { rit, a tempo, rit, a tempo pogo pǘ (ma non tonto), } \\
\text { apressando wn pouco, netendo, Tempo primo, Lento, } \\
\text { rall, Tempo primo, rall, a tempo pogo rall. }\end{array}$ \\
\hline$N^{*} 6$ & Alegretio & $\theta=\mathbf{8 0}$ & $\begin{array}{l}\text { (como won negato fluente) } \\
\text { Tranguito (wom pouco menos) expressivo }\end{array}$ & $2 / 4,5 / 4,3 / 4,2 / 4$ & poco piu, roll, Lento, Tempo I \\
\hline$N^{n 7}$ & Alkgo & $\theta=\mathbf{8 8}$ & - & c & rall, a tempo (poco nubato), roll, a tempo. \\
\hline$N^{*} 8$ & & $\theta=60$ & - & $3 / 4,7 / 4,3 / 4$ & $\begin{array}{c}\text { pouquisssimo affretando, a tempo, poco nuboto, rall, a } \\
\text { tempo, affretando, rall, Tempo I, nubato, molto } \\
\text { expressivo }\end{array}$ \\
\hline$N^{29} 9$ (1950) & Moderato & - & - & 4/4 & poco roll, roll \\
\hline op. $2 N^{2} 9$ (1998) & & - & Ritmico, com simplicidode & $2 / 2$ & 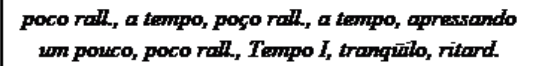 \\
\hline$N^{n} 10(1998)$ & Moderato & $\begin{aligned} \theta=58 \\
(\text { minima) }\end{aligned}$ & molto expreassivo & 4/4 & ad. Wh., etéreo, a tempo, com hberdade \\
\hline
\end{tabular}

Tab. 5: Indicações de Andamento, Marcação Metronômica (M.M.), Fórmula de Compasso (F.C.), Caráter e Variação de Agógica. Fonte: Hamond (2005, p.60).

Podemos classificar o emprego do pedal quanto à troca, podendo ser sincopada ou rítmica, e quanto à profundidade, através do pedal inteiro, do meio pedal ou do 1/4 de pedal. $\mathrm{O}$ uso do pedal, a sua troca e a profundidade a ser utilizada vai depender da sua função dentro de cada peça ou trecho dela. O pedal sincopado pode ser usado na maior parte dos prelúdios. O pedal rítmico é uma boa escolha no Prelúdio op.2 № 9 . 0 pedal inteiro, com a função de produzir o efeito de ressonância, pode ser empregado nos Prelúdios № 4 e $N$ ㅇ 6 . O meio pedal, para sustentar as notas pedal e limpar a sequência de acordes ou notas, pode estar presente no Prelúdio $N$ № 9 (1956). O pedal tonal pode ser usado quando uma nota pedal soar durante um compasso inteiro ao mesmo tempo em que uma melodia diatônica precisa ser clara: este é o caso do Prelúdio № 2 (c. 1-17), ${ }^{15}$ onde uma semibreve é sustentada através do pedal tonal e as terças duplas são ligadas através do uso criterioso do pedal direito sincopado, evitando que as ressonâncias das notas duplas se acumulem.

A utilização do pedal una corda pode estar associada à mudança de timbre, de sonoridade, de caráter e até mesmo de dinâmica, $p$ e pp em alguns casos. As sonoridades aveludadas e suaves podem ser valorizadas com o seu emprego. É interessante escolher o seu uso na repetição final de um tema, como acontece no Prelúdio No 4 (c. 46-67); ou pela indicação de caráter como um regato, fluente e de dinâmica $p$ no Prelúdio № 6 (c. 1-28), com o uso concomitante do pedal direito. Da mesma forma, o não uso do pedal 
pode ser uma escolha do intérprete e é subentendido pelo caráter da peça, como acontece em alguns trechos do Prelúdio op.2 № 9, através da indicação Rítmico com simplicidade. A seguir, uma análise musical dos onze prelúdios de Villani-Côrtes é realizada a fim de ressaltar aspectos técnico-interpretativos, além da identificação do potencial pedagógico no ensino de piano.

\section{Prelúdio № 1}

O Prelúdio № 1 foi uma das primeiras composições para piano de Villani-Côrtes. $\mathrm{Na}$ época, o compositor começava a estudar piano e a pesquisar modulações no instrumento. Sua intenção foi "um treino de tocar dó, ré, mi, fá, sol" com "espírito mais contemplativo, mais suave, meio perdido", que se confirma na M.M. $\theta=128$ indicada na partitura (VILLANI-CÔRTES, 2004a).

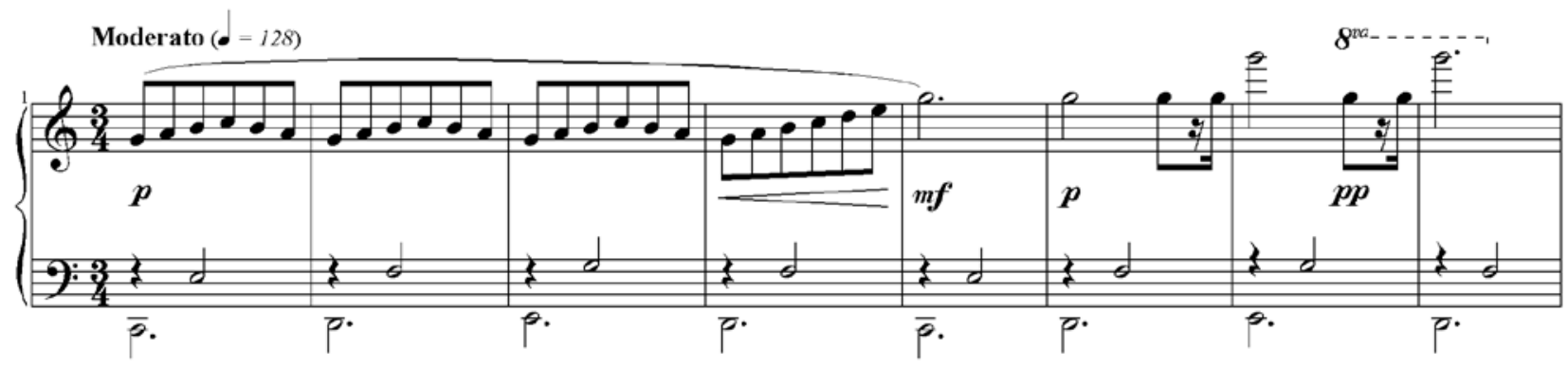

Exemplo 1.1: Prelúdio No 1 (c. 1-8). Fonte: Hamond (2005, p.64).

O movimento cíclico do tema nos remete ao vai e vem das ondas do mar, que inicialmente é brando, mas de repente nos surpreende com uma maior amplitude e depois retorna à calmaria. O compositor classifica essa peça como minimalista: a melodia da mão direita repete o mesmo motivo, apesar da mudança da harmonia na mão esquerda. ${ }^{16}$ Sobre a questão da continuidade, podemos admitir que a peça permite um andamento um pouco superior à M.M. $\theta=128,{ }^{17}$ como indicado na partitura. Ao adotar um andamento mais andado, ainda em Moderato, com a indicação M.M. $\theta=144$, podemos contar mais facilmente um pulso por compasso, o que facilita a construção das frases longas e confere um caráter mais movido e fluente. No entanto, o compositor relatou que a interpretação do Prelúdio № 1 a M.M. $\theta=144$ apresenta "um caráter um pouco mais virtuosístico, mais pé no chão, mais decidido, mais vigoroso", suspeitando desta execução ser mais funcional (VILLANI-CÔRTES, 2004a). Porém, ao adotar a indicação M.M. $\theta=128$, a dinâmica pode ser mais explorada e o intérprete pode "sugar mais cada nota" (VILLANI-CÔRTES, 2004a).

Na parte A (c. 1-16), as ligaduras de frase na mão direita (m.d.) solicitam um toque legato combinado com o uso cuidadoso do pedal direito para ressaltar a linha melódica

\footnotetext{
16 A partir daqui utilizaremos a abreviação m.d. para designar mão direita e m.e. para designar mão esquerda.

17 Apesar da M.M. = 128 não se apresentar no metrônomo, realizamos uma extrapolação para um andamento intermediário ao M.M. = 126 e M.M. = 132.
} 
e a progressão de décimas. A repetição do tema (c. 9-16) apresenta um caráter mais intimista, devido à mudança na textura e no registro do acompanhamento, e direciona para um toque velado pela presença da dinâmica pp indicada dois compassos antes.

A parte B (c. 17-28) apresenta o tema invertido com a mesma forma cíclica da parte A. O acompanhamento da mão esquerda (m.e.) fica mais dissonante e denso, apresentando acordes quebrados de quatro sons, ainda com pedal na dominante. A parte C (c. 35-49) é a mais contrastante e se subdivide em três seções. A presença de marchas harmônicas, de variações no caráter, mais dramático, na agógica e no andamento, através do poco piú, faz com que essa parte seja passível de explorar diferentes sonoridades. O intérprete deve enfatizar a melodia da m.d. e equilibrar o toque nos planos sonoros do acompanhamento.

O prelúdio finaliza com uma Coda (c. 58-73), com caráter ingenuamente, resgata elementos presentes nas partes B e C e apresenta o tema invertido. Esta linha melódica é semelhante ao tema de Amanhecer da Suite Peer Gynt de Edward Grieg (1843-1907).

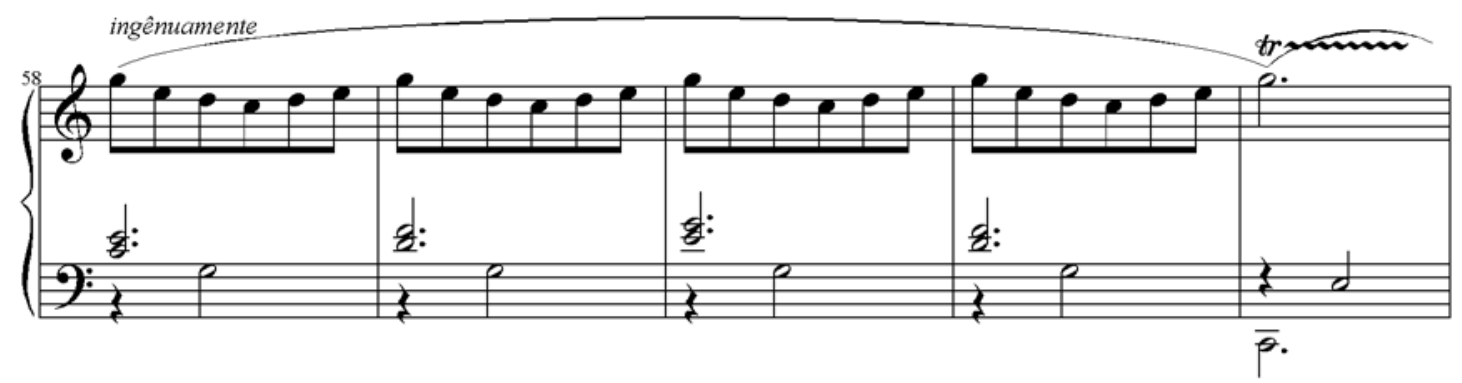

Exemplo 1.2: Prelúdio No 1 (c. 58-62). Fonte: Hamond (2005, p.67).

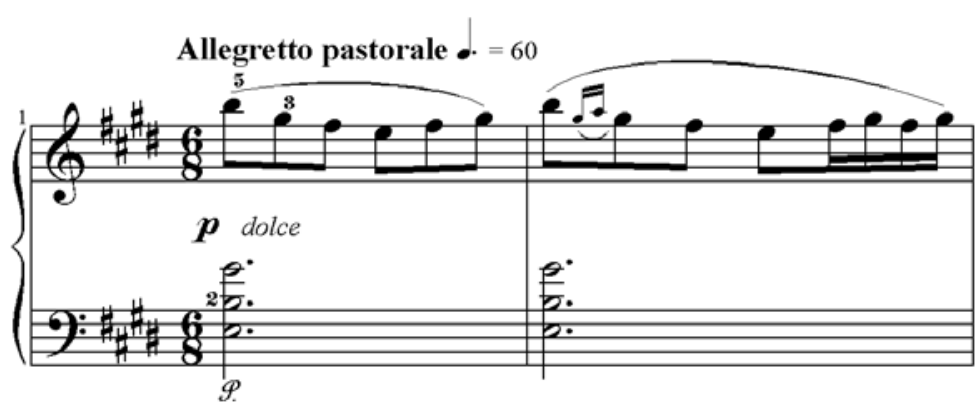

Exemplo 1.3: Amanhecer da Suite Peer Gynt No 1, Op 46 (c. 1-2) de Grieg. Fonte: Hamond (2005, p.68).

O trillo no c. 62 é um dos poucos momentos em que Villani-Côrtes escreve ornamentos nos prelúdios: o toque deve ser delicado e brilhante. Um arpejo ascendente conduz à escala cromática (c. 68-72), que nos remete a um glissando. Este é um dos momentos mais fluentes do prelúdio, onde o intérprete deve manter o legato e a direção da frase de uma frase longa.

Ao identificar o potencial didático do Prelúdio № 1, foi possível observar as seguintes habilidades técnicas desenvolvidas: legato em passagens escalares na m.d.; igualdade na continuidade de colcheias; abertura da mão na extensão de $8^{a}$ na m.d.; oitavas na m.d. e m.e.; abertura da m.e. na extensão de 10 ${ }^{a}$ (com sustentação de nota pedal); presença de terças na m.e.; acordes de três e quatro sons (quebrados ou em blocos); 
deslocamento rápido da m.e. (saltos de oitavas para acordes); ornamentação na m.d.: trinados e arpejos rápidos (c. 54; c. 62-65; c. 73); escala cromática descendente com intervalo de 4a justa entre m.d. e m.e.; movimento alternado das mãos para execução de arpejos (c.66-67); movimento de rotação da m.d. (c.21-24) através da repetição de uma nota intercalada com uma sequência diatônica descendente; variação da agógica e mudança no tempo através de rall, Tempo I, poço piú, dentre outros; uso de pedal direito com troca sincopada.

\section{Prelúdio № 2}

A principal característica deste prelúdio é a apresentação de escala pentatônica e a ocorrência de quatro planos sonoros distribuídos em diferentes registros do piano, conforme podemos observar no exemplo 2.1 .

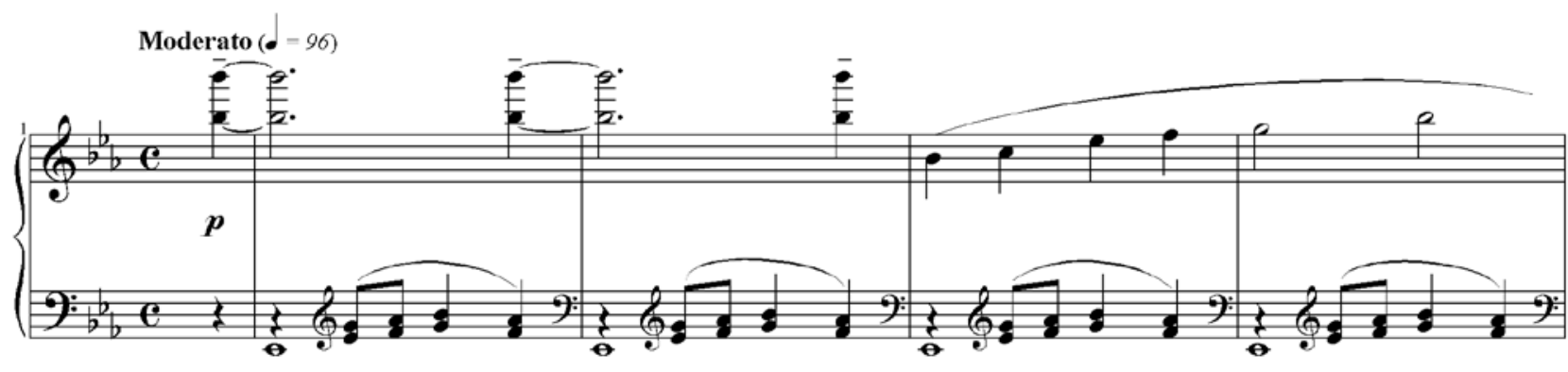

Exemplo 2.1: Prelúdio No 2 (c. 1-4). Fonte: Hamond (2005, p.69).

A parte A (c. 3-18) mostra o tema no desenho em que é construído: sobre a escala pentatônica de Mi b maior, nos remetendo ao ambiente sonoro oriental. Os planos sonoros continuam a ser apresentados e podem ser ressaltados com diferenciação no toque dos planos sonoros, o baixo e as terças duplas na mão esquerda, e a melodia e as oitavas na mão direita, e através do uso de pedal. O pedal direito com troca sincopada pode ser usado para controlar a sonoridade desejada e auxiliar no toque claro e em legato das terças duplas. $O$ uso do pedal tonal é uma sugestão interessante, pois sustenta os baixos. ${ }^{18}$ O maior desafio técnico-interpretativo para o pianista está em controlar a dinâmica, a articulação, o toque, além de equilibrar a sonoridade de cada plano. Uma sugestão para a interpretação musical é através da diferenciação de toque e dinâmica em cada plano sonoro e da realização das articulações características de cada um dos planos.

A parte $A^{\prime}$ (c.19-31) contrasta em relação à parte $A$ no que diz respeito ao discurso com notas duplas (m.d.) e no acompanhamento, em arpejos (m.e.). Ocorre um gradual aumento da densidade sonora da m.d., pelo acréscimo de uma, duas ou de até três notas em cada acorde. O ritmo do acompanhamento confere um caráter mais movido ao trecho. A dramaticidade deste prelúdio é observada pela modulação do material temático para tons afastados, como Sol b maior, lá maior e dó maior (c. 23-25) e pela presença de marcha harmônica (c. 25-26), que conduzem ao ponto culminante da peça (c. 26): maior 
dinâmica $(m f)$ e exploração de registros agudos, médios e graves do piano. $O$ intérprete deve estar atento às mudanças harmônicas (c. 22-25), como por exemplo Mi b maior, Sol b maior, Lá maior e Dó maior, buscando expressar e valorizar essas surpresas, criando uma expectativa sobre qual direção harmônica o compositor quer alcançar. A condução dos três acordes sucessivos e repetidos (c. 26-29) deve ser executada realizando um decrescendo. Um momento totalmente novo e inesperado ocorre na peça nos c. 30-31: a apresentação simultânea de uma linha melódica e de uma passagem rápida de arpejos, com efeito de appogiatura, com caráter improvisatório e cadencial.

A revisão da peça junto com o compositor foi necessária e válida, resultando nas seguintes anotações, conforme mostra o Exemplo 2.2: 1) nota Mi b (semínima) m.d., c. 30 e ligadura unindo a nota Mi b, m.d., c. 29, à nota Mi b acrescentada, m.d., c. 30; 2) acidente (bequadro) na nota Sol do quarto tempo, m.d., c. 30.

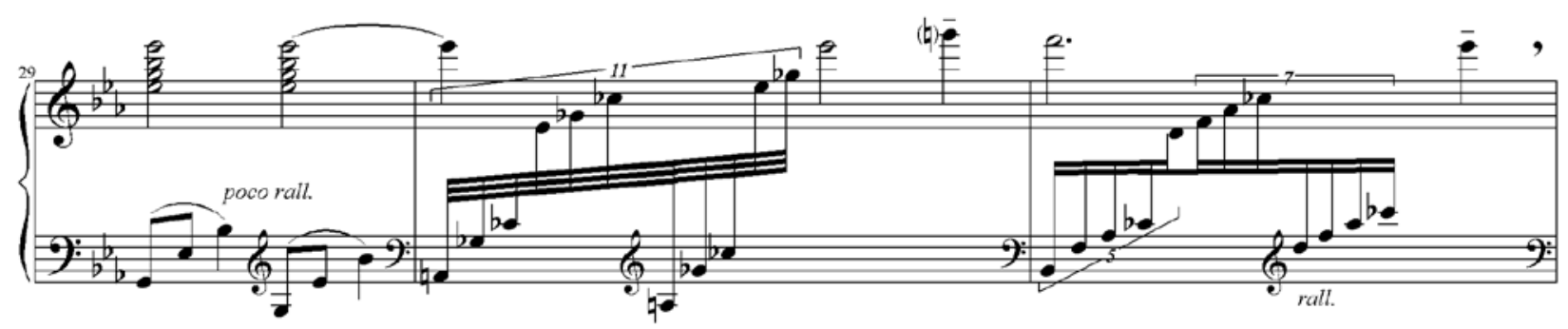

Exemplo 2.2: Prelúdio No 2 (c. 29-31). Fonte: Hamond (2005, p.70).

Para esta parte, Villani-Côrtes declarou que sua intenção foi ressaltar a voz superior, fazendo com que o arpejo representasse apenas uma condução para a melodia principal. Desta forma, a continuidade da linha melódica superior foi priorizada em relação à sequência de notas arpejadas. $O$ intérprete deve buscar um toque diferente para a voz superior, timbrando a voz superior e realizando um toque mais suave para as fusas e semicolcheias arpejadas em mãos alternadas, de modo que ressoe a harmonia resultante dessas notas de passagem, pensando o trecho como sendo executado por uma orquestra.

A Coda (c. 32-39) reapresenta uma parte do tema, ora em Mi b maior (c. 32 e 34), ora em Sol b maior (c. 33 e 35). A oscilação harmônica nos remete à linguagem composicional de Debussy, mais especificamente em Claire de Lune (c. 27), da Suíte Bergamasque.

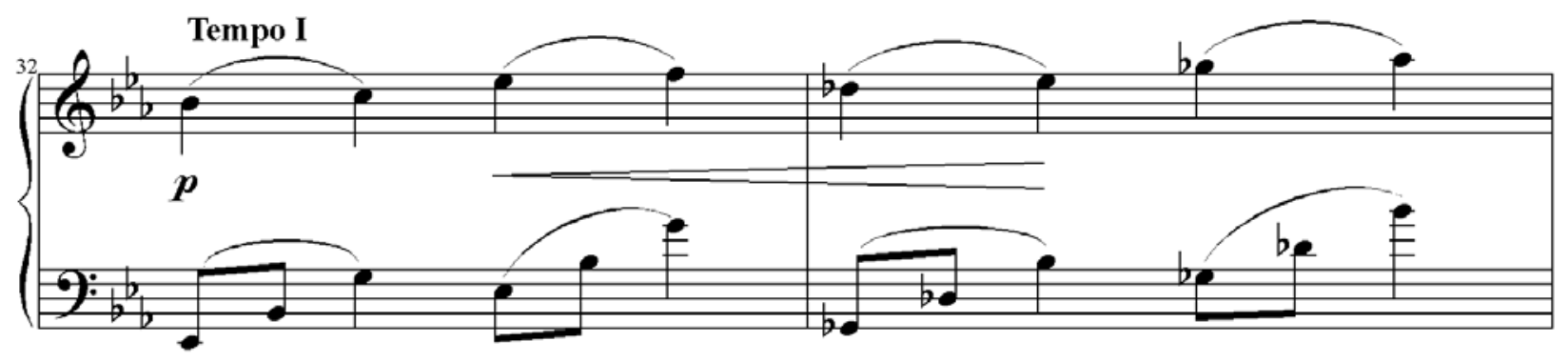

Exemplo 2.3: Prelúdio No 2 (c.32-33). Fonte: Hamond (2005, p.71). 


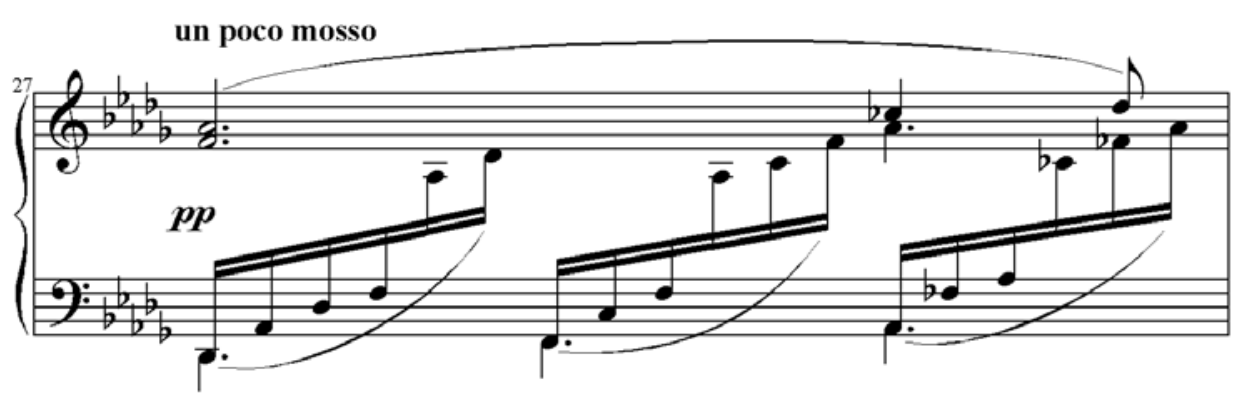

Exemplo 2.4: Claire de lune (c. 27) da Suite berguemasque, de Debussy. Fonte: Hamond (2005, p.71).

Ao identificar o potencial didático do Prelúdio № 2, foi possível observar as seguintes habilidades técnicas desenvolvidas: quatro planos sonoros: melodia (tema na m.d.) e acompanhamento (nota pedal e terças duplas na m.e. e oitavas na m.d.); riqueza de recursos timbrísticos; legato em passagens escalares (pentatônica); possibilidade de substituição de dedo; legato em notas duplas na m.d. (c. 19-21); legato em terças duplas na m.e. (c. 1-17); acordes de três e quatro sons na m.d. (c. 19-39); abertura da m.e. nos arpejos (c. 19-39); movimento alternado das mãos para execução de arpejos e passagens escalares (c. 30-31); oitavas (c. 1-2; c. 9-10); saltos entre notas pedal e terças duplas na m.e. (c. 1-17); ornamentação: arpejos de execução rápida com efeito de apojatura (c. 30-31); variação da agógica através de perdendo-se (c. 37), poco rall (c. 29), rall (c. 31) e rall até o fim (c. 34); pedal direito com troca sincopada, pedal tonal para sustentação das notas pedal da m.e. (c. 1-17) e possibilidade do una corda (c. 32-39).

\section{Prelúdio № 3}

Os elementos que melhor caracterizam este prelúdio são a presença de síncopes, de tercinas e de cromatismo. As indicações de caráter e andamento são suficientes para delimitar a forma desse prelúdio. Uma análise mais profunda mostra que essas partes se diferenciam também em ritmo, textura e dinâmica.

$\mathrm{O}$ ritmo sincopado alternado com tercinas marca a entrada do tema na parte $\mathrm{A} \mathrm{e}$ está presente tanto na melodia quanto no acompanhamento.

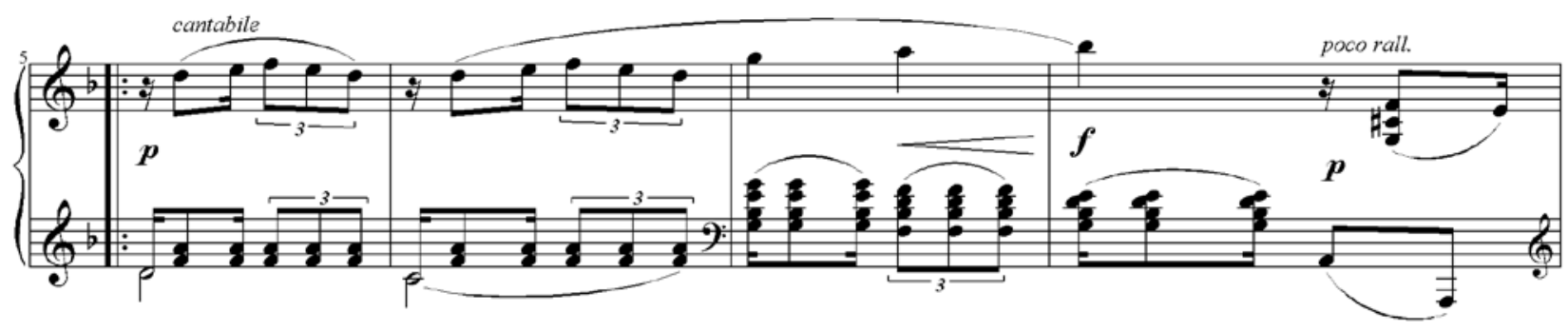

Exemplo 3.1: Prelúdio No3 (c. 5-8). Fonte: Hamond (2005, p.74).

Num primeiro momento, o intérprete, ao se deparar com essa variação de padrões rítmicos - síncopes e tercinas -, poderia pensar em seguir rigorosamente a partitura e executar esses ritmos de maneira muito precisa. Na verdade, o autor comenta que sua inten- 
ção é a de tocar um padrão rítmico meio parecido com o outro, como se toca na música popular: sem seguir "o rigor da escrita" (VILLANI-CÔRTES, 2004a). Segundo o compositor, a sua visão didática da peça está justamente em realizar uma execução que aproxime os padrões rítmicos da síncope (meio tercinada) e da tercina (meio sincopada), ou seja, executar essas passagens sem rigidez metronômica. Ao revisar a peça com o compositor, ele comentou que este prelúdio é um samba-canção meio saudoso, meio dolente.

Ao identificar o potencial didático do Prelúdio № 3, foi possível observar as seguintes habilidades técnicas desenvolvidas: textura homofônica (melodia acompanhada); legato em passagens escalares; intercalação de ritmo sincopado e tercinas (execução no estilo de música popular); notas presas na m.e. (c. 5-6; c. 9-10; c. 13; c. 15-17); terças repetidas e acordes de quatro sons repetidos na m.e. (c. 5-21); abertura das mãos na extensão de 8a․ na m.e. (c. 8, c. 12; c. 25) e na m.d. (c. 26-29); oitavas; acordes de três sons na m.d. e de quatro sons na m.e.; ornamento: arpejo em passagem rápida (c. 28); agógica variada: poco rall (c. 8), a tempo (c. 9, c. 21), affretando [sic] (c. 18), rall (c. 19, c. 25 , c. 29), Lento (c. 26); pedal direito com troca sincopada e rítmica.

\section{Prelúdio № 4}

As características mais marcantes deste prelúdio são as alternâncias de ritmo e de textura (homofônica e polifônica). A obra apresenta um continuum, ora de semicolcheias, ora de tercinas, por meio de arpejos ou passagens escalares realizados através da alternância entre as duas mãos, que é apresentado do início ao fim do prelúdio e nos remete à fluência de uma peça escrita para harpa.

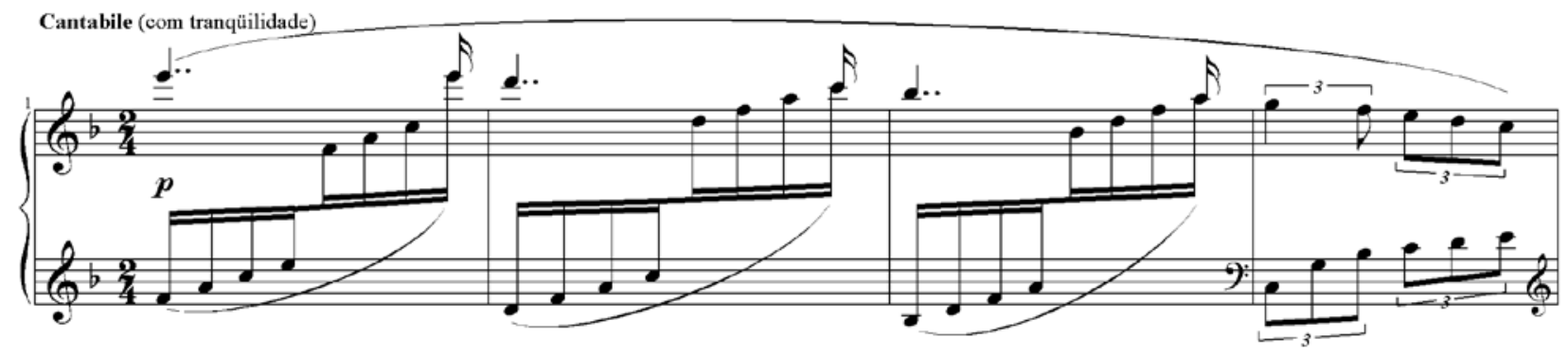

Exemplo 4.1: Prelúdio No 4 (c. 1-4). Fonte: Hamond (2005, p.76).

Devido à quantidade de repetições do tema, o intérprete deve conduzir o prelúdio de modo que este não fique monótono, através de diferentes sonoridades, toques e agógica. Sugerimos a utilização de pequenos rallentandi, não escritos originalmente pelo compositor, nos finais de frases e pequenos accelerandi nos meios de frases, promovendo uma variação da agógica. A utilização do pedal direito é recomendada, pois favorece a ressonância da harmonia, porém o seu uso deve ser cauteloso quanto à profundidade nos grupos de tercinas, onde a clareza e a independência das conduções de vozes são requeridas.

Ao identificar o potencial didático do Prelúdio № 4, foi possível observar as seguintes habilidades técnicas desenvolvidas: legato em passagem extensa na m.e. e m.d.; 
arpejos na m.d. e m.e.; abertura da mão na extensão de 7ạ na m.d. e m.e.; igualdade das semicolcheias; nota presa com substituição de dedo e mudança de dedilhado (c. 1-28; c. 46-67); subdivisões ora em semicolcheias, ora em tercinas (c. 1-28; c. 46-67); precisão em padrões rítmicos diferentes; mudança de fórmula de compasso; saltos na m.d. e m.e. (c. 39-45); legato em notas duplas na m.d. (c. 39-45); timbragem de nota superior da m.d. (melodia); movimento alternado das mãos pela execução de arpejos (c. 1-38; c. 46-67); cruzamento de mãos e saltos com distância de oitavas (c. 39-45; c. 63-65); presença de acento e tenuta; variação na agógica: rall (c. 37; c. 44), a tempo (c. 39; c. 46; c. 58), menos (c. 65); pedal direito com troca sincopada e una corda (reexposição do tema).

\section{Prelúdio № 5}

O prelúdio apresenta-se como uma valsa e é caracterizado por uma oitava seguida de uma superposição de acordes de três e quatro sons combinados entre as duas mãos, através dos quais ocorre uma condução de vozes.

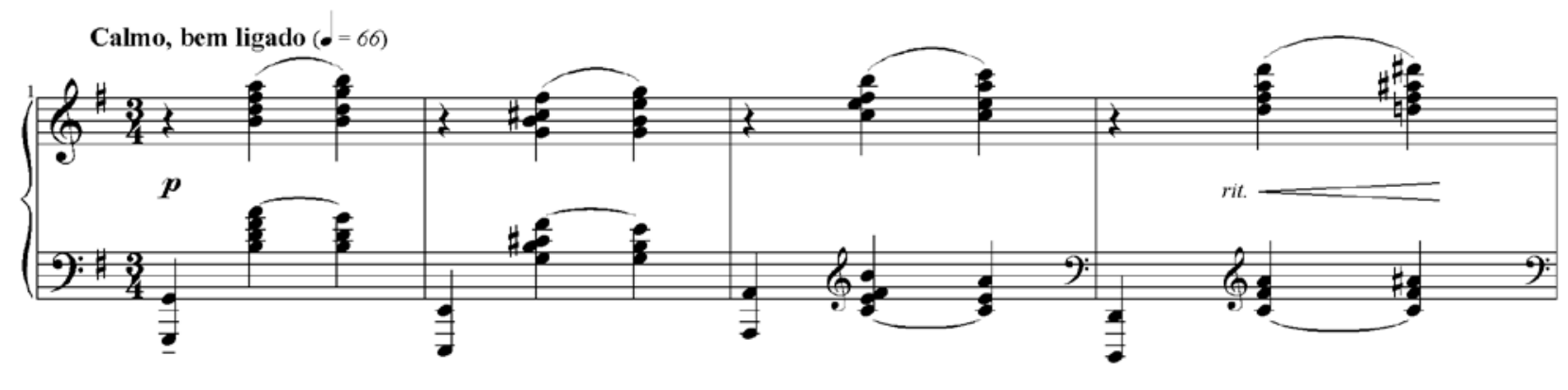

Exemplo 5.1: Prelúdio No 5 (c. 1-4). Fonte: Hamond (2005, p.80)

Este prelúdio apresenta o tema na parte A (c. 1-8) e A' (c. 18-29), na tonalidade de Sol maior, repetido duas vezes: uma oitava seguida de dois acordes, que nos remete a uma dança. A melodia e o acompanhamento se confundem, pois as duas linhas melódicas resultam das vozes superiores dos acordes de cada mão, devendo ser timbradas pelo intérprete.

A parte $B$ (c. 9-17) se assemelha à parte $A$ em termos da disposição dos acordes, porém contrasta nas suas relações intervalares, que agora ocorre em terças descendentes, e nas progressões harmônicas, que se mostram mais presentes e constantes. Ao contrário da parte $A$, os acordes superpostos movimentam-se paralelamente. Apesar de a dinâmica se manter em $\mathrm{p}$, o intérprete deve buscar sonoridades e toques que valorizem as conduções melódicas e as mudanças na harmonia. O c. 29 é o único momento em que ocorrem arpejos em mãos alternadas no prelúdio, contrastando com os momentos predominantes de oitavas e acordes. Este é um elemento que oferece certa liberdade de execução ao intérprete, através também da mudança de andamento para Lento, e pontua a estrutura da peça. 


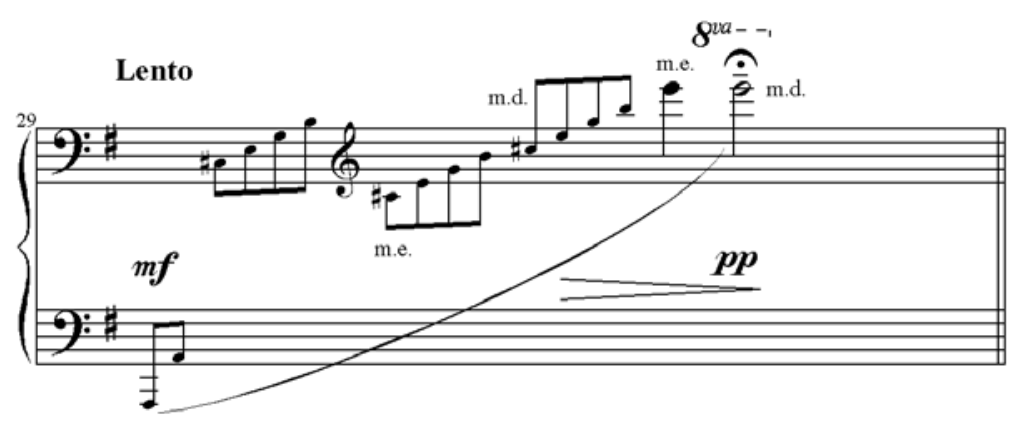

Exemplo 5.2: Prelúdio No5 (c. 29). Fonte: Hamond (2005, p.81).

$\mathrm{Na}$ Coda (c. 30-36) o padrão estrutural - nota pedal seguida de dois acordes superpostos - é retomado e ocorre como uma dissolução, através do decrescendo gradual e retenção do andamento ( $r a l l)$, conduzindo a uma sonoridade mais suave. Entendemos que o intérprete pode conceber uma sonoridade mais velada, através do uso simultâneo dos pedais una corda (esquerdo) e sustain (direito) com troca sincopada.

Ao identificar o potencial didático do Prelúdio № 5, foi possível observar as seguintes habilidades técnicas desenvolvidas: oitavas na m.e.; abertura da mão na extensão de 8a ; saltos entre oitavas e acordes de quatro sons na m.e.; legato entre acordes na m.d. e m.e.; acordes de quatro sons na m.d. e m.e.; movimento paralelo das mãos nos acordes (c. 9-14; c. 35); timbragem de nota superior do acorde: $5^{\circ}$ e $4 \stackrel{0}{\circ}$ dedos da m.d. e $2^{\circ}$ e 1ำ dedos da m.e.; arpejos em mãos alternadas (c. 29); riqueza de recursos timbrísticos; legato em passagens extensas (c. 29); movimento alternado das mãos para execução de arpejo (c. 29); presença de tenuta (c. 35-36); variação na agógica: rit (c. 4, c. 8), a tempo (c. 5; c. 35), a tempo poco più (ma non tanto) (c. 9), apressando um pouco (c. 15), retendo (c. 17), rall (c. 33), poco rall (c. 35); pedal direito com troca sincopada e una corda.

\section{Prelúdio № 6}

A principal característica deste prelúdio é a apresentação de dois momentos musicais distintos que contrastam em registro, textura, timbre, andamento e caráter: o primeiro apresenta zonas de ressonância da harmonia criadas por arpejos, criando uma atmosfera "impressionista", revivendo Claude Debussy e lembrando a execução numa harpa, conforme o Exemplo 6.1.

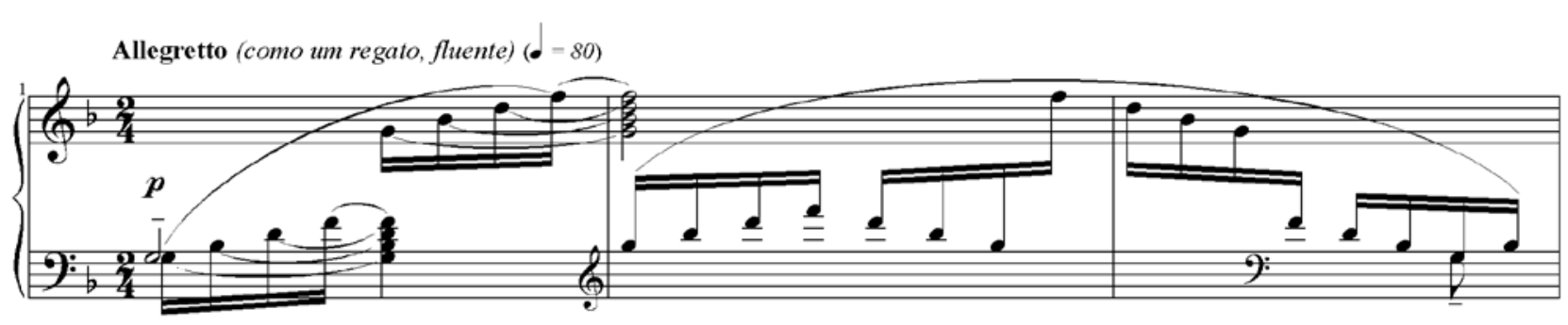

Exemplo 6.1: Prelúdio No 6 (c. 1-3). Fonte: Hamond (2005, p.83). 
Pensar num compasso 3/4 para a parte $A$ (c. 1-28) auxilia o intérprete, pois expressa um movimento ascendente e descendente, ressaltando a progressão harmônica, como sugere o Exemplo 6.2:

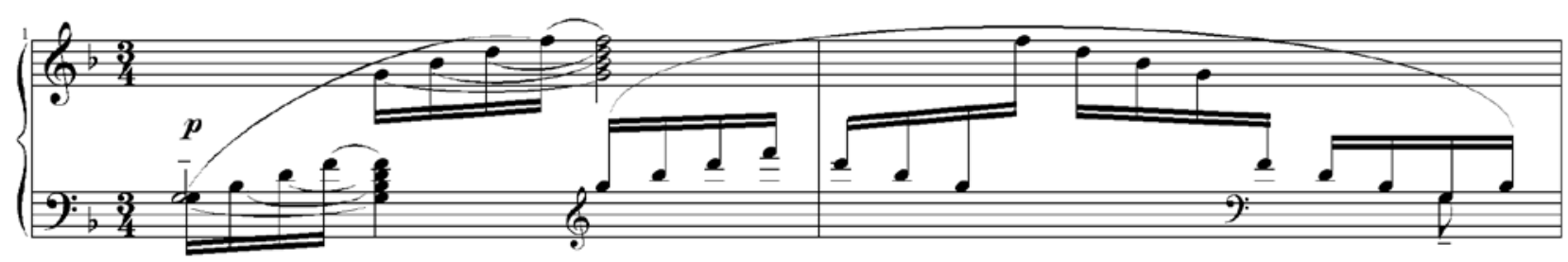

Exemplo 6.2: Prelúdio Nº 6 (c. 1-3) modificado. Fonte: Hamond (2005, p.84).

A progressão harmônica com acordes arpejados de 7ạ convidam o intérprete para uma exploração de sonoridades nas quais as ressonâncias devem ser enfatizadas, criando um ambiente sonoro instável e flutuante. O planejamento do fraseado deve levar em conta o formato parabólico do discurso, exigindo do intérprete a realização de um crescendo até atingir a nota mais aguda e um decrescendo até a nota mais grave, pontuando a linha melódica do baixo. O continuum de semicolcheias pode ser alcançado através da combinação controlada entre legato de dedo e uso dos pedais, pensando sempre na preservação do movimento rítmico contínuo das figuras para obter o ambiente sonoro indicado. O pedal una corda pode ser usado desde o início para conferir uma sonoridade velada.

Na parte B (c. 29-44) há o estabelecimento do centro tonal em fá maior, além de um estilo mais jazzístico, nos remetendo à escrita de personalidades da música popular americana, como Henry Mancini, ou até mesmo à linguagem de Maurice Ravel, conforme o Exemplo 6.3. Há uma breve citação de um dos temas da Pavane pour une infante défunte, de Ravel, como podemos ilustrar a seguir.

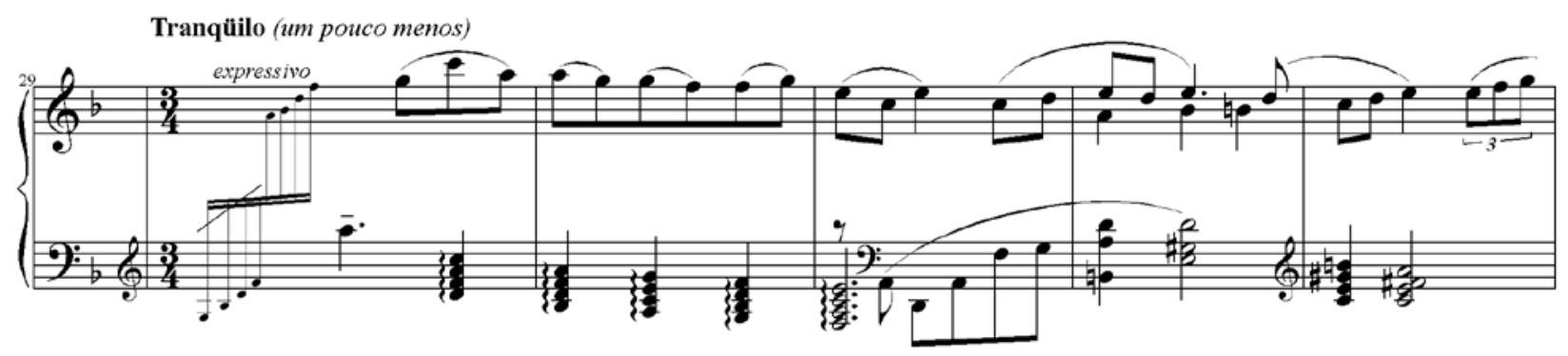

Exemplo 6.3: Prelúdio No 6 (c. 29-33). Fonte: Hamond (2005, p.83). 

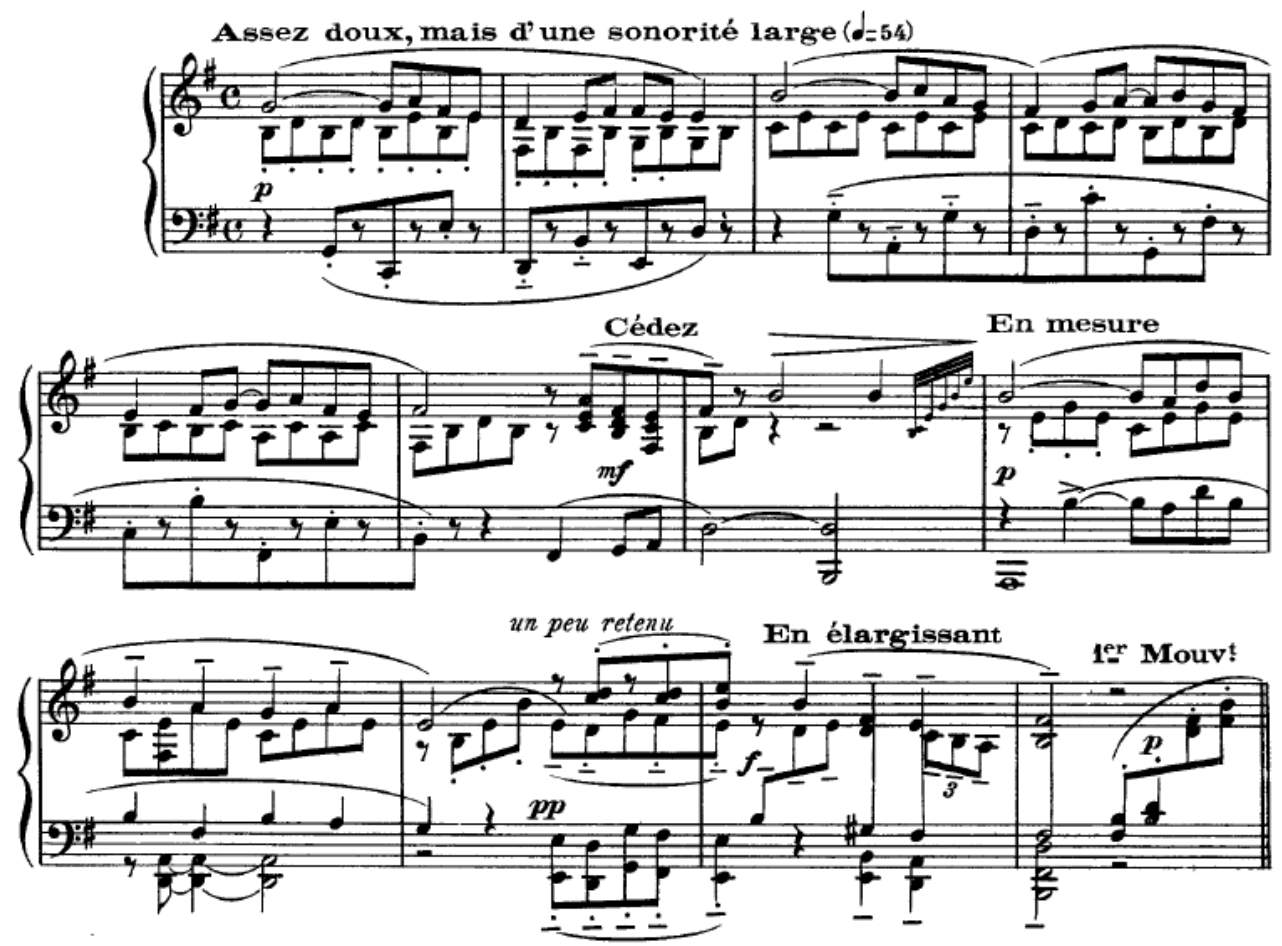

Exemplo 6.3: Pavane pour une infante défunte, de Ravel (Mineola: Dover Publications, 1986). Fonte: IMSLP. ${ }^{19}$

Ao identificar o potencial didático do Prelúdio № 6, foi possível observar as seguintes habilidades técnicas desenvolvidas: legato em passagem extensa; timbragem de notas inferiores da m.e.; igualdade de semicolcheias (c. 1-28, c. 54-85); arpejos nas m.d. e m.e.; movimento alternado com cruzamento das mãos para execução de arpejos; possibilidade de substituição de dedo; sustentação de notas nos arpejos; controle de sonoridade; mudança de fórmula de compasso; acorde de quatro sons na m.e.; ornamentação: arpejo com efeito de apojatura (c. 29-30; c. 38-40), apojatura (c. 53) e apojatura com efeito de glissando (c. 86); deslocamento métrico ou de acentuação no compasso (c. 45-52); notas duplas com cruzamento de mãos (c. 84-85); pedal direito com troca sincopada e rítmica e una corda.

\section{Prelúdio № 7}

Os elementos mais caractsticos deste prelúdio são as modulações e os cromatismos. Construído como uma colcha de retalhos, este prelúdio apresenta materiais composicionais que nos remetem à escrita de autores como Prokofiev, Debussy e Chopin. A diversidade e o contraste de registro, textura, dinâmica, andamento, caráter e forma são evidentes. A peça, em tonalidade de Sol maior, é mais brilhante e virtuosística, apresenta um caráter mais decidido, contrastando com a natureza introspectiva e contemplativa dos outros prelúdios, conforme podemos observar no Exemplo 7.1. 


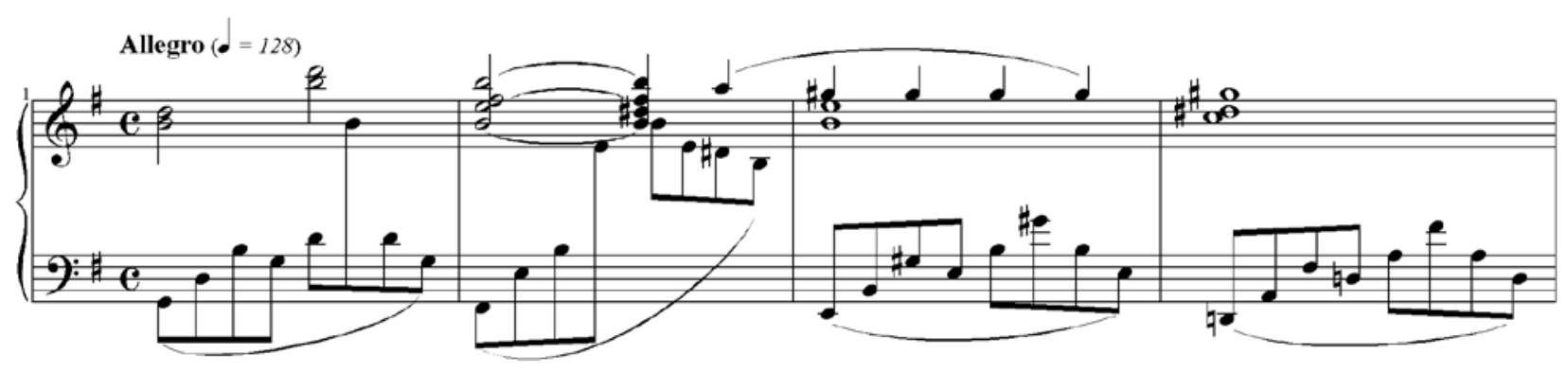

Exemplo 7.1: Prelúdio No 7 (c. 1-4). Fonte: Hamond (2005, p.87).

A parte A (c. 1-8) apresenta o tema tético (c. 1-4), uma melodia em terças duplas na m.d. acompanhada por arpejos na m.e., repetida duas vezes. A primeira transição (c. 9-15) apresenta arpejos na m.e. e acordes na m.d. com movimento paralelo e cromático, usando uma superposição de acordes dissonantes. ${ }^{20}$ Este cromatismo conduz, através de uma marcha harmônica ascendente, ao primeiro ponto culminante da peça (c. 12), devido aos saltos e à exploração de registros sonoros.

A parte B (c. 28-33) é súbita e vigorosa, caracterizada por saltos e acordes com dinâmica em fortíssimo e a presença de tercinas. Este trecho nos remete à escrita de Debussy, mais especificamente ao ritmo de um trecho de Claire de Lune (c. 15), da Suíte Bergamasque:

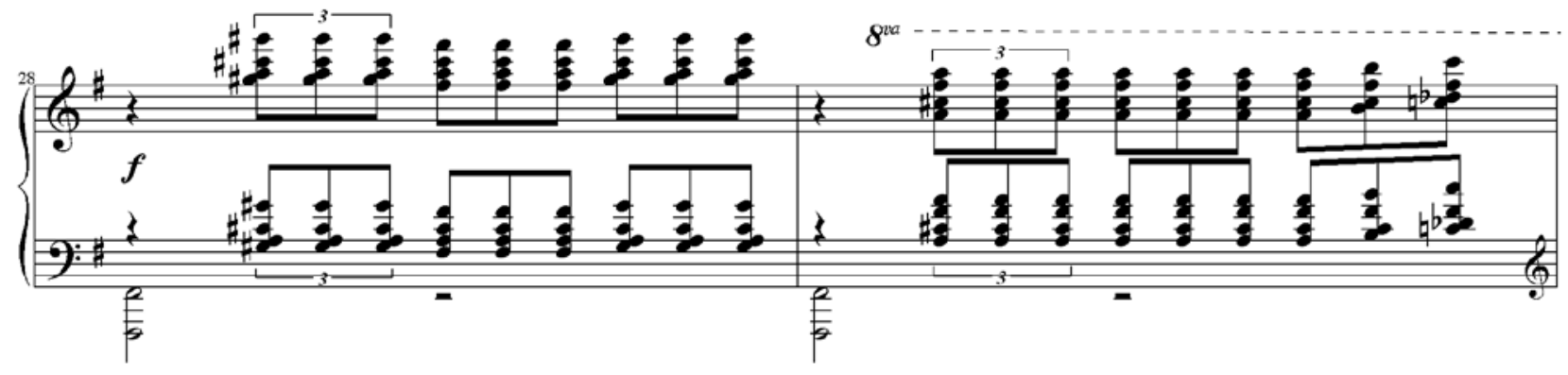

Exemplo 7.2: Prelúdio No 7 (c. 28-29). Fonte: Hamond (2005, p.89).

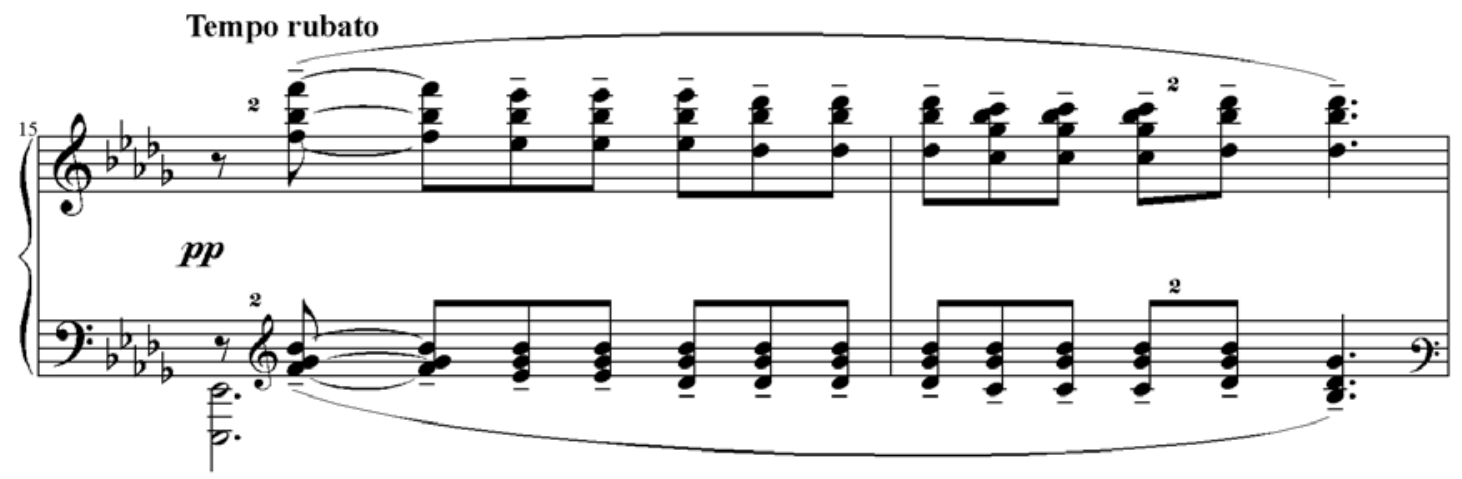

Exemplo 7.3: Claire de Lune (c. 15-16), da Suite Bergamasque, de Debussy. Fonte: Hamond (2005, p.89). 
Sugere-se que o intérprete toque claramente os últimos acordes em tercinas, de modo que estes deem um impulso para o ponto culminante da peça (c. 30): superposição de acordes de quatro sons em dinâmica ff com grandes saltos e alta densidade sonora. Neste trecho (c. 30-33), o intérprete precisa estar consciente das constantes mudanças de configuração das mãos para cada acorde tocado, das rápidas mudanças de registro e, ao mesmo tempo, precisa ter um controle da dinâmica, que segue um gradual decrescendo.

A transição (c. 34-41) é uma dissolução do material e é dividida em dois momentos. O primeiro é uma passagem descendente, ou melhor, um movimento em cascata de um acorde quebrado em notas duplas e superposto nas duas mãos, com mudança na agógica, agora em rubato. O intérprete deve se lembrar de que o rubato conta com inflexões de andamento, porém deve fazê-lo sem comprometer a continuidade da frase musical. Neste trecho o intérprete necessita alterar rapidamente a configuração das mãos, o que nos remete a um trecho do Estudo op.10 № 3 de Chopin (c. 46-47).

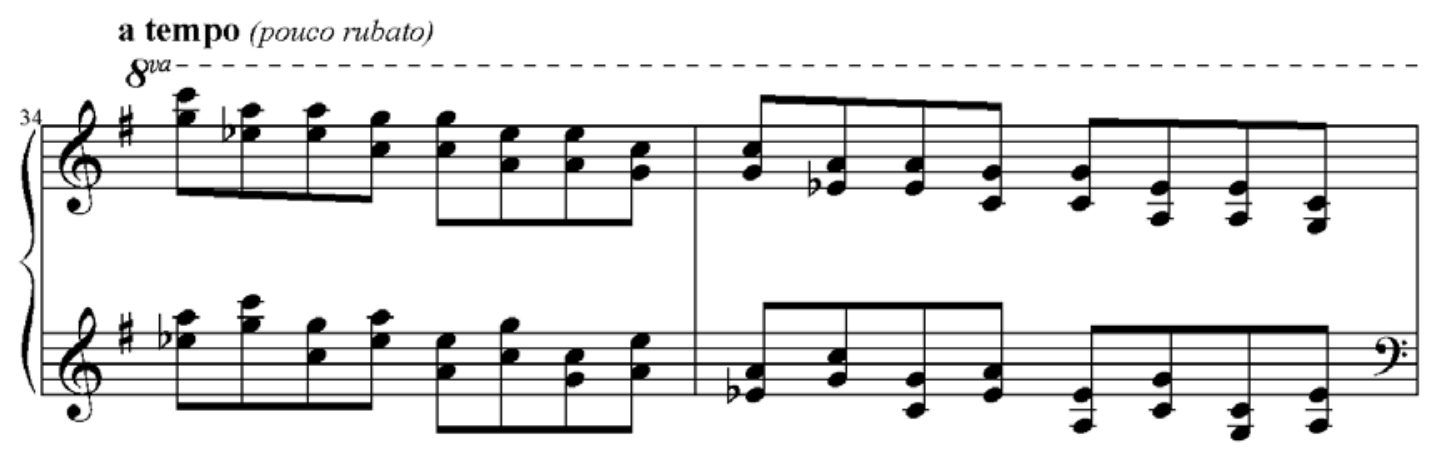

Exemplo 7.4: Prelúdio No 7 (c. 34-35). Fonte: Hamond (2005, p.90).

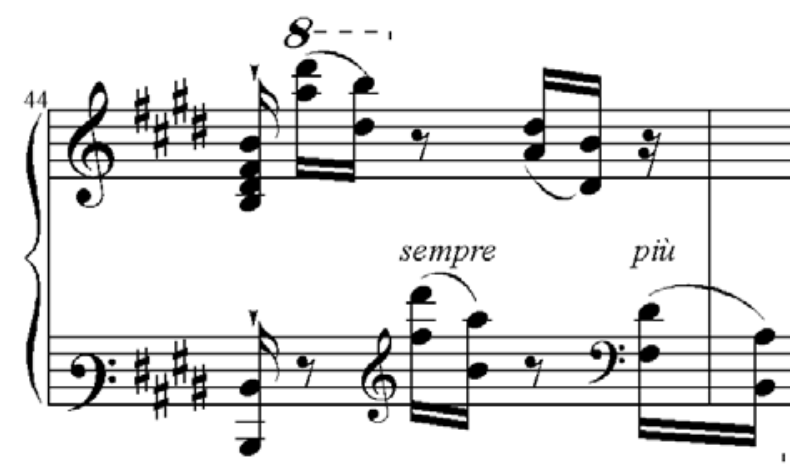

Exemplo 7.5: Estudo op.10 No 3 (c. 44), de Chopin. Fonte: Hamond (2005, p.90).

O segundo momento (c. 38-41) é a execução de arpejos ascendentes com mãos alternadas, em ré maior, dominante da tonalidade, conduzindo à cadência e à retomada do tema (c. 42). Apesar de esperarmos o agrupamento de quatro em quatro colcheias, como acontece num compasso quaternário, a articulação indicada segue a alternância das mãos, ocorrendo de três em três colcheias e devendo soar desta maneira. 


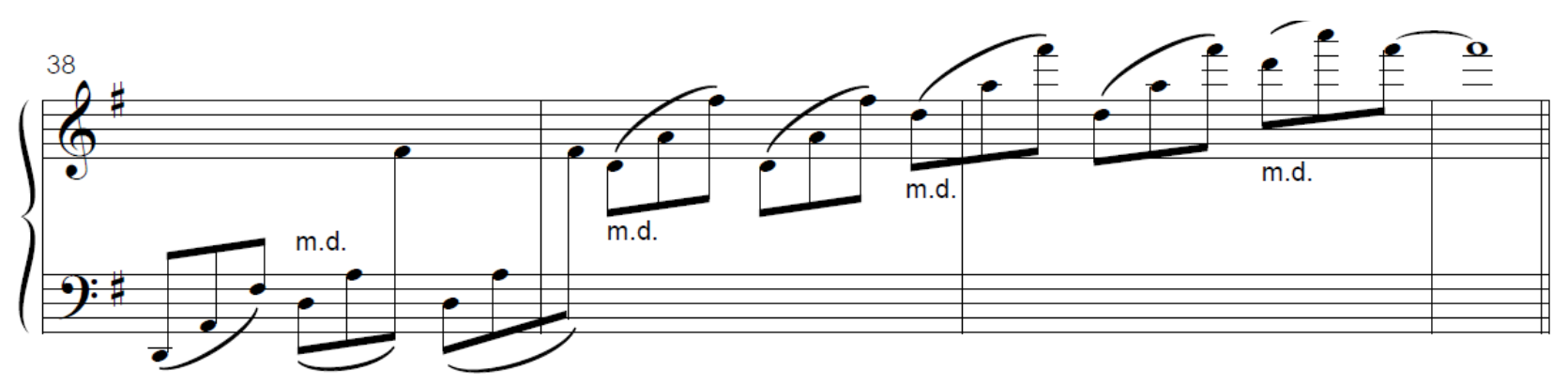

Exemplo 7.6: Prelúdio Nº 7 (c. 38-41). Fonte: Villani-Côrtes (2015, p.19).

Uma revisão da partitura foi proposta junto ao compositor durante a pesquisa. Ao realizar a revisão da partitura, Villani-Côrtes adicionou indicações de dinâmica, de agógica e de toque no texto musical, que esclarecem dúvidas e direcionam o estudo técnico-interpretativo do pianista. Os exemplos a seguir mostram as alterações:

1) M.M. $\theta=126$ e dinâmica $m f$, c. 1 , no Exemplo 7.7:

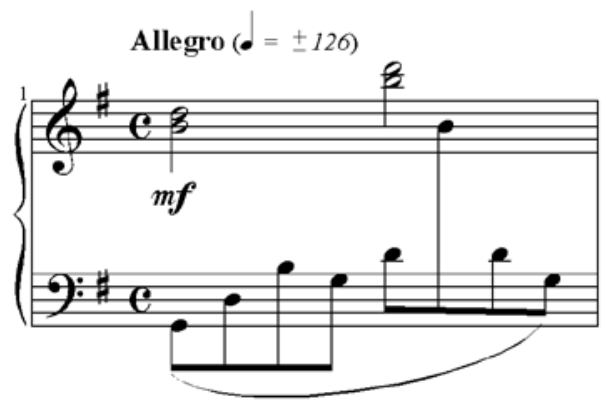

Exemplo 7.7: Prelúdio No 7 (c. 1). Fonte: Hamond (2005, p.91).

2) Variação de dinâmica e de agógica, c. 9-16, tenutas, c. 12 e c. 14, ligaduras de expressão, c. 13, no Exemplo 7.8:
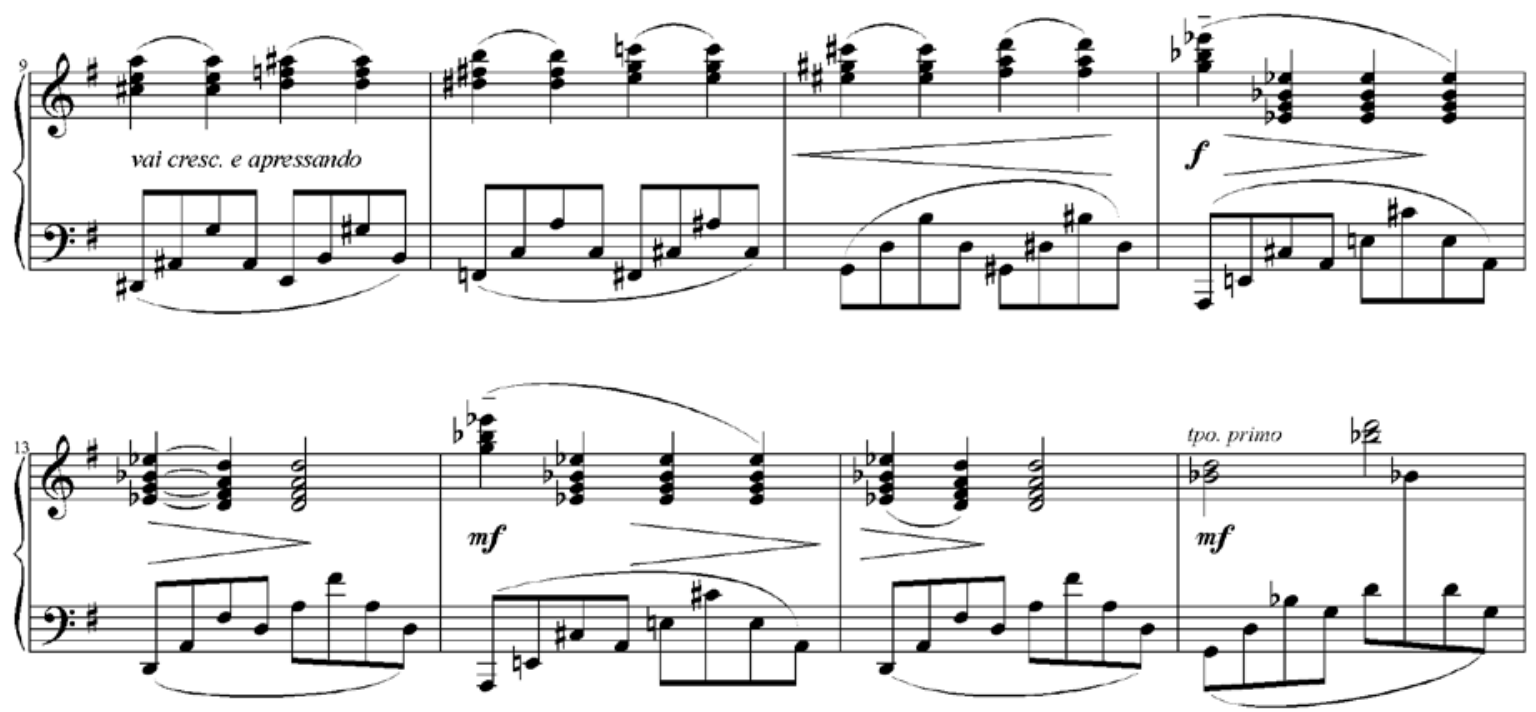

Exemplo 7.8: Prelúdio No 7(c. 9-16). Fonte: Hamond (2005, p.91). 
3) Variação de dinâmica e de tempo, c. 23-25, no Exemplo 7.9:

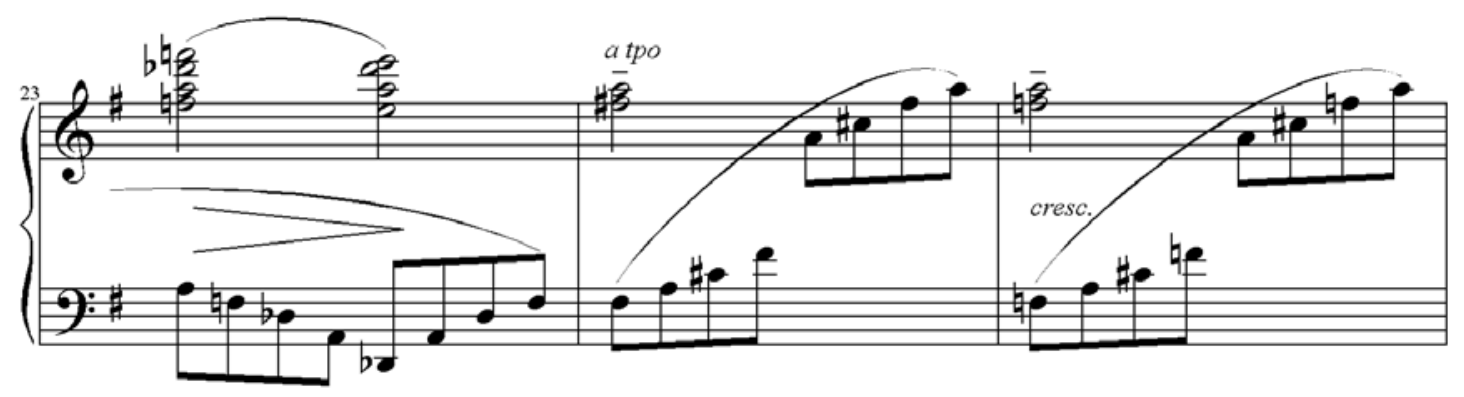

Exemplo 7.9: Prelúdio No 7 (c.23-25). Fonte: Hamond (2005, p.91).

4) Variação de tempo, c. 42, no Exemplo 7.10:

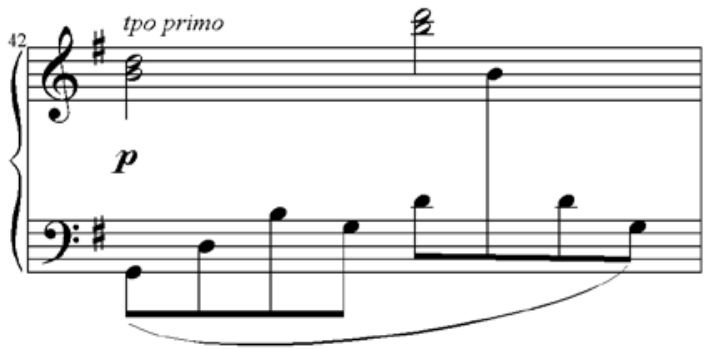

Exemplo 7.10: Prelúdio No 7 (c. 42). Fonte: Hamond (2005, p.92)

5) Dinâmica f, c. 48 e c. 50, e indicação de 8ª acima, c. 49, no Exemplo 7.11:

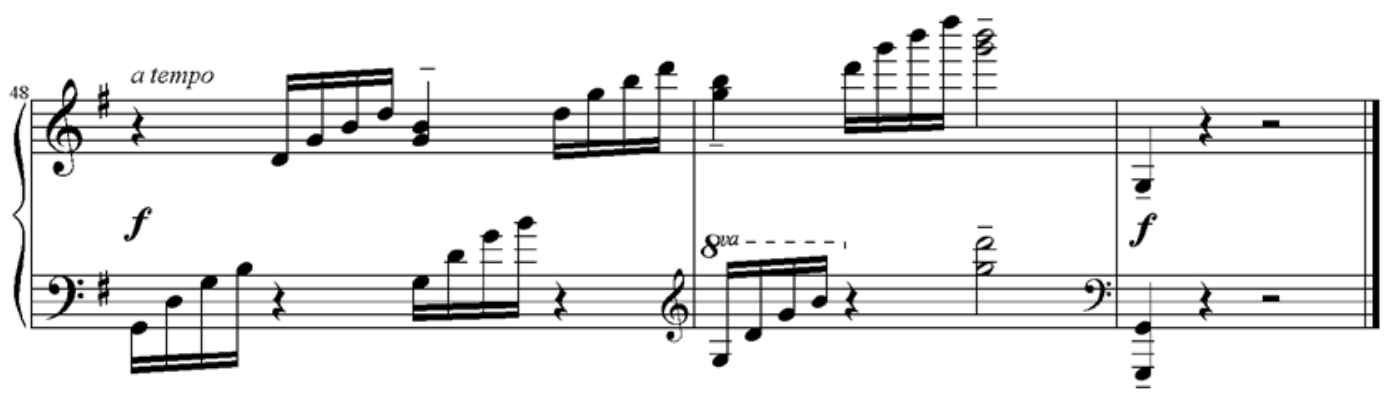

Exemplo 7.11: Prelúdio No 7 (c. 48-50). Fonte: Hamond (2005, p.92).

Ao identificar o potencial didático do Prelúdio № 7, foi possível observar as seguintes habilidades técnicas desenvolvidas: substituição de dedo na m.d. (c. 1, c. 5, c. 17, c. 42); legato em arpejos na m.e.; notas repetidas (c. 3, c. 7) e acordes repetidos (c. 9-15, c. 18 , c. 22 , c. $28-33$, c. 44 ); movimento alternado para execução de arpejos (c. 24-27; c. 38-41; c. 48-49); saltos de acordes com extensão de uma oitava (c. 20 e 21); abertura de mão na extensão de 8a ; oitavas; saltos na m.e. de oitavas para acorde (c. 28-29) com mudança rápida de posição; saltos com deslocamento rápido de acordes e notas terças repetidas na m.d. e quintas na m.e. (c. 30-33); movimento paralelo das mãos (c. 30-37); acordes de quatro sons na m.d. e m.e.; abertura entre dedos em acordes de quatro sons (c. 29); notas duplas nas duas mãos (c. 34-37) com movimento simétrico e paralelo; pedal direito com troca sincopada. 


\section{Prelúdio № 8}

A qualidade mais marcante deste prelúdio é a presença de um tratamento da harmonia coral. $\mathrm{O}$ cromatismo descendente também é apresentado, conferindo um caráter denso à peça. Combinações de situações contrastantes utilizando diferentes registros e dinâmicas contribuem para a configuração da peça, conforme podemos verificar no Exemplo 8.1.

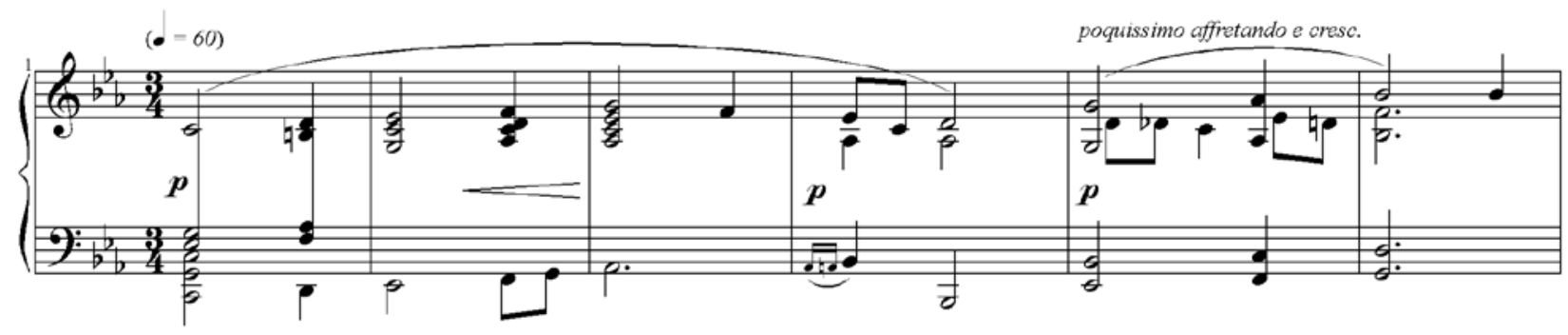

Exemplo 8.1: Prelúdio No 8 (c. 1-6). Fonte: Hamond (2005, p.93)

Interessante é observar que até mesmo neste prelúdio Villani-Côrtes faz citações sutis (Exemplo 8.2). Especialmente neste caso o elemento cromático nos remete ao segundo tema de Rhapsody in Blue, de George Gershwin (Exemplo 8.3). Há possibilidade do uso do pedal una corda para c. 25-30.

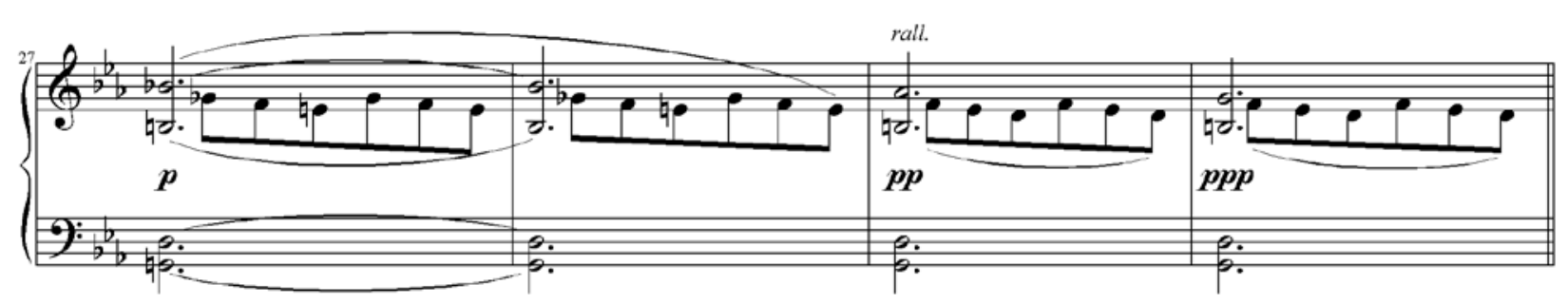

Exemplo 8.2: Prelúdio No 8 (c. 27-30). Fonte: Hamond (2005, p.95). 

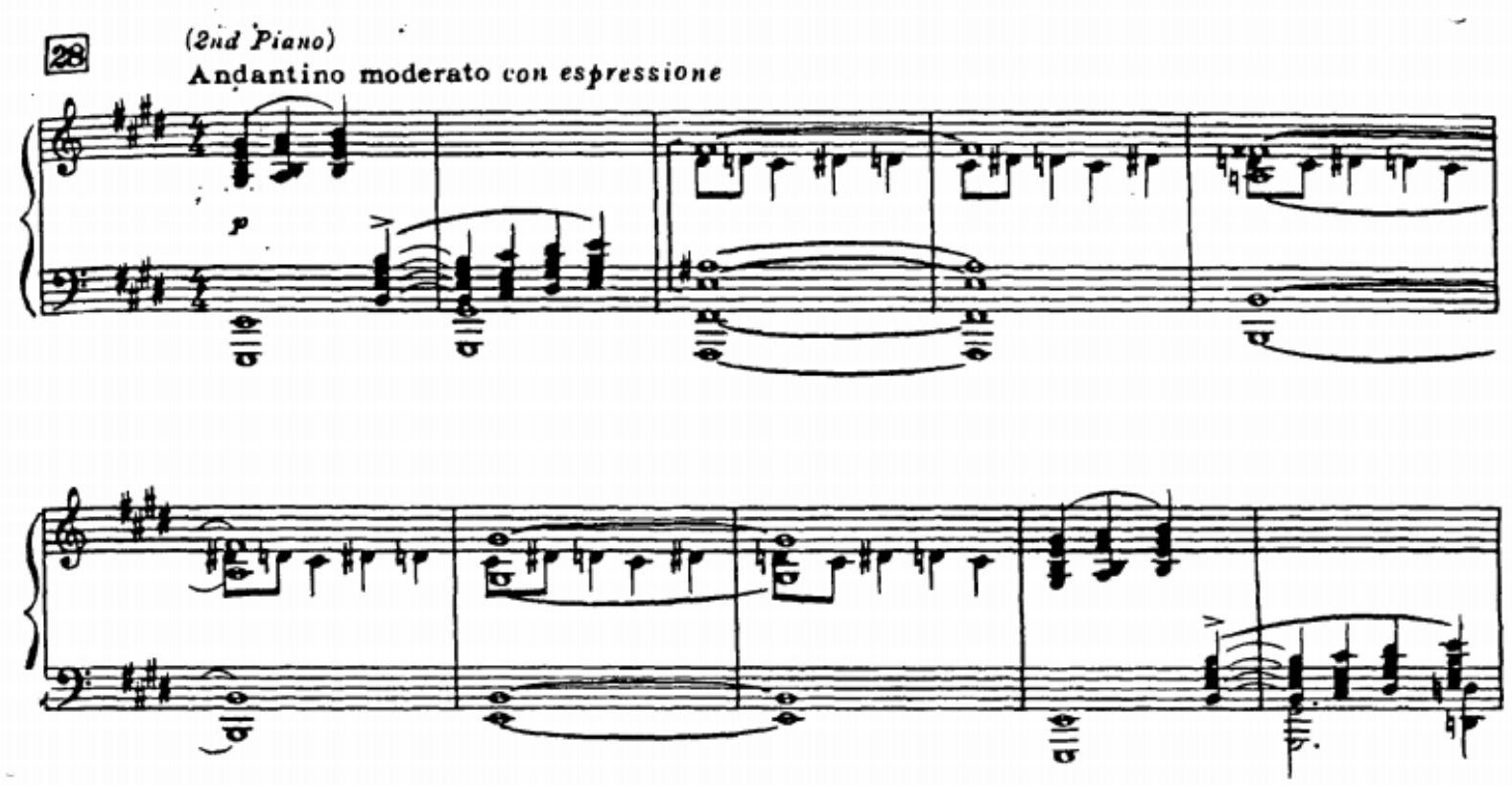

Exemplo 8.3: Andantino do Rhapsody in Blue, de Gershwin (New York: New York Music Corp., 1924). Fonte: IMSLP. ${ }^{21}$

$\mathrm{Na}$ Codeta (c. 31-33) o prelúdio atinge seu máximo em dinâmica e variação da agógica, através das indicações fortíssimo, sfz, rubato, molto expressivo, ampliação da fórmula de compasso, para 7/4 (c. 31-32), e aumento da densidade sonora, com a inclusão de acordes pedais na região grave e uma mesma linha melódica triplicada em oitavas diferentes na região aguda do teclado. Todos esses elementos são contrastantes em relação ao restante do prelúdio e revelam um caráter declamatório, até então não esperado, que finaliza com um acorde na região grave em compasso $3 / 4$ (c. 33). O intérprete deve ressaltar os sfz (c. 31-33), únicos acentos indicados na série dos prelúdios. Este trecho exige do pianista um deslocamento rápido das mãos, em movimento paralelo, e controle de sonoridade através dos diferentes registros. A execução das semicolcheias deve ser bem incisiva, segundo o compositor, imaginando a peça escrita para orquestra (VILLANI-CÔRTES, 2004a).

Ao identificar o potencial didático do Prelúdio № 8, foi possível observar as seguintes habilidades técnicas desenvolvidas: acordes de três e quatro sons na m.d.; legato de acordes em passagem extensa; legato em notas duplas; substituição de dedo; movimento paralelo das mãos; riqueza de recursos timbrísticos; três planos sonoros; oitavas; quintas na m.e.; condução de voz intermediária (c. 5, c. 21-30); legato em passagens escalares diatônicas; saltos entre acordes e oitavas (c. 31-33); mudança de fórmula de compasso; oitavas como notas presas e dedilhado com extensão entre os dedos 4 e 5 na m.d. (c. 21-30); ornamentação: apojaturas na m.e. (c. 4; c. 17); agógica variada: pouquíssimo affretando [sic] e cresc. (c. 5); rall (c. 9), a tempo (c. 10), poco rubato (c. 12), a tempo (c. 14) cresc e affretando [sic] (c. 20) rall (c. 29) Tempo I e rubato, molto expressivo (c. 31); pedal direito com troca sincopada. 


\section{Prelúdio № 9 (1956)}

As principais características do Prelúdio № 9 (1956) são o lirismo, a presença de síncopes e a imitação melódico-rítmica, conforme mostra Exemplo 9.1:

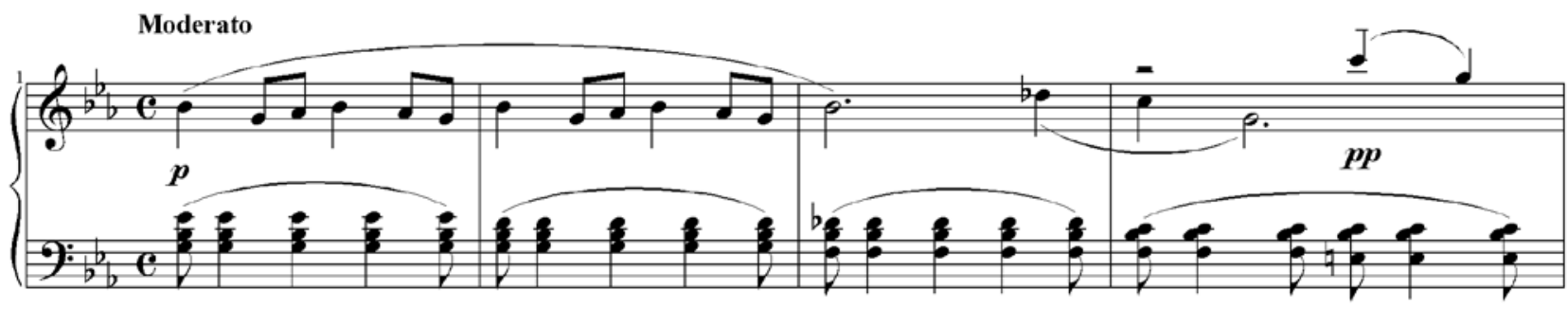

Exemplo 9.1: Prelúdio No 9 (1956) (c. 1-4). Fonte: Hamond (2005, p.104).

Em grande parte, a dinâmica predominante é p em toque legato, o que deve exigir do intérprete absoluto controle de toque. A mudança de textura (c. 14-15) confere uma maior dramaticidade e um contraste de material. $O$ intérprete deve mostrar o contraste súbito entre um trecho (c. 14-16), com dinâmicas ff e o caráter brilhante, e outro seguinte (c. 16-20), que nos remete ao retorno do tema, diluído, com dinâmica $p$ e natureza calma, conforme mostra o Exemplo 11.2. Após o acorde em ff (c. 16), há o retorno da atmosfera de estabilidade.

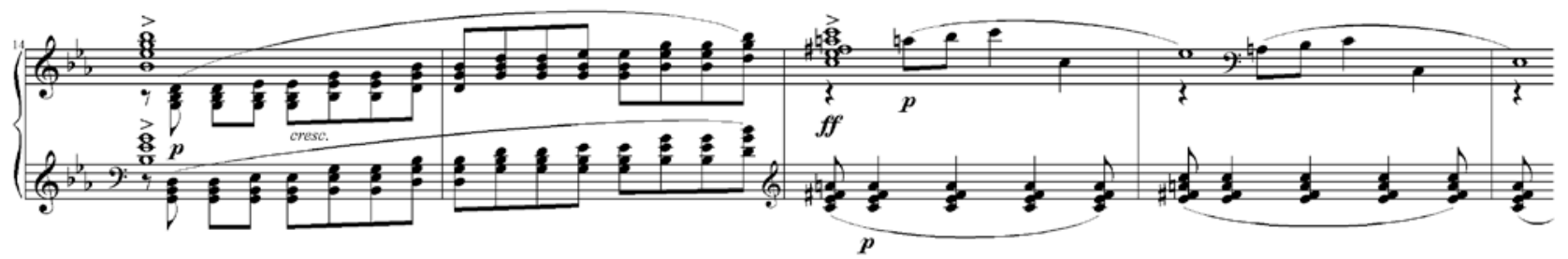

Exemplo 9.2: Prelúdio No 9 (1956) (c. 14-18). Fonte: Hamond (2005, p.105).

A Coda (c. 21-24) inicia-se com o retorno do tema, mas uma oitava acima, com o mesmo acompanhamento de acordes repetidos, e apresenta mudanças na agógica, únicas em todo o prelúdio: poco rall (c. 20), a tempo (c. 21) e rall (c. 23), o que favorece uma liberdade de condução do discurso musical pelo intérprete.

Ao identificar o potencial didático do Prelúdio No 9 (1956), foi possível observar as seguintes habilidades técnicas desenvolvidas: legato em passagem extensa; possibilidade de substituição de dedo; acordes repetidos e em ritmo sincopado na m.e. (c. 1-11, c. 13, c. 16-22); controle de sonoridade e de timbre; arpejos na m.e. (c. 12; c. 23); mudanças de posição e deslocamentos rápidos: saltos na m.d. (c. 4, c. 8, c. 16-20) e na m.e. (c. 21-22); acordes de três sons nas duas mãos; acordes de quatro sons na m.d.; movimento paralelo das mãos, com saltos e superposição de acordes (c. 14-16); abertura de mão na extensão de 8 ; ; pedal direito com troca sincopada. 


\section{Prelúdio op.2 № $9^{22}$}

Este prelúdio apresenta como principais características o uso do ritmo sincopado, a exploração da harmonia e a presença de cromatismo e de texturas variadas. O prelúdio apresenta uma harmonia que nos remete ao jazz e à bossa nova, com a utilização da escala de blues e de modalismo. O caráter Rítmico, com simplicidade oferece uma liberdade de escolha do intérprete quanto ao andamento e à marcação metronômica, ambos não indicados. Uma boa opção para o intérprete é adotar andamento Moderato e a M.M. $\theta=92$. Nota-se nas primeiras notas o centro tonal em Dó, com a utilização de escala de blues e passagens modais, e no final o centro tonal em Dó é restabelecido (Exemplo 10.1).

A repetição da nota Dó aliada ao ritmo sincopado e à progressão harmônica (c. 4-5) é um dos momentos em que podemos reviver elementos da música popular brasileira, como por exemplo o Samba de uma nota só, de Tom Jobim (que foi gravada em 1960).

Acordes dissonantes em marcha harmônica ascendente e cromática conduzem o início da Coda (c. 22(2)-30), formada por três frases curtas, em caráter tranquilo, apresentando o padrão: um acorde pedal, em registro grave, seguido de uma linha melódica dobrada em oitavas.

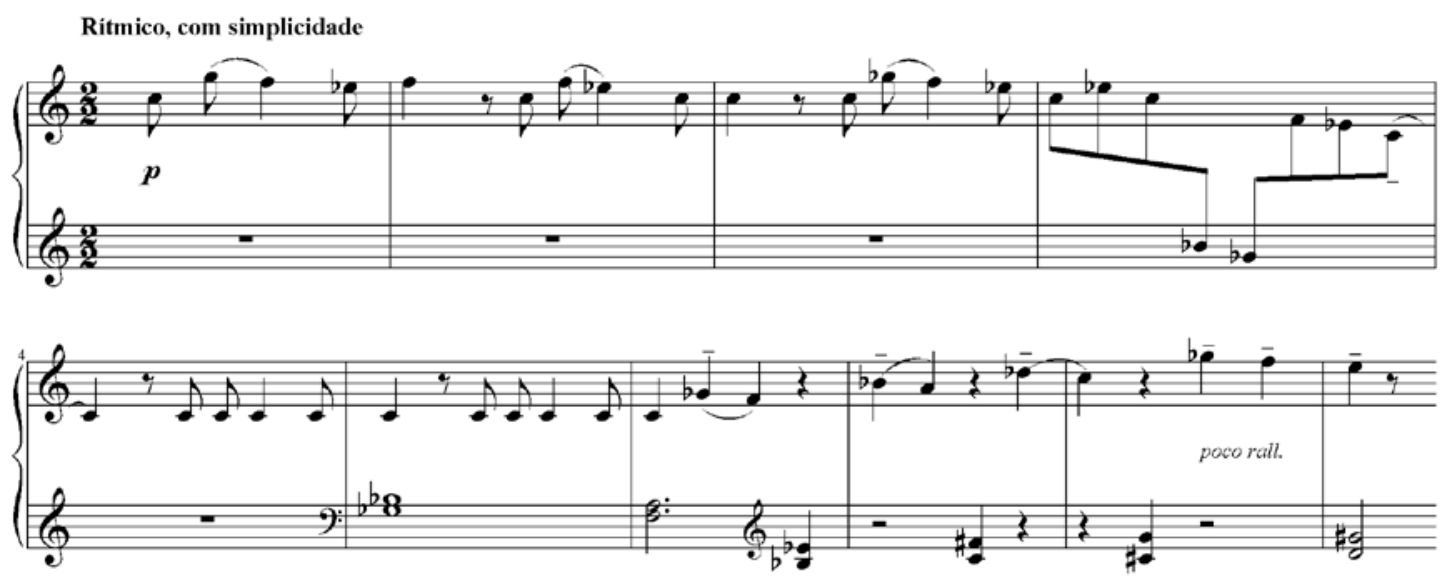

Exemplo 10.1: Prelúdio op. 2 № 9 (c. 1-9). Fonte: Hamond (2005, p.97).

Segundo Villani-Côrtes (2004b), esta indicação da dinâmica mf para o acorde é intencional, de modo que a zona de ressonância formada pelo acorde perdure até o final do prelúdio (Exemplo 10.2). 


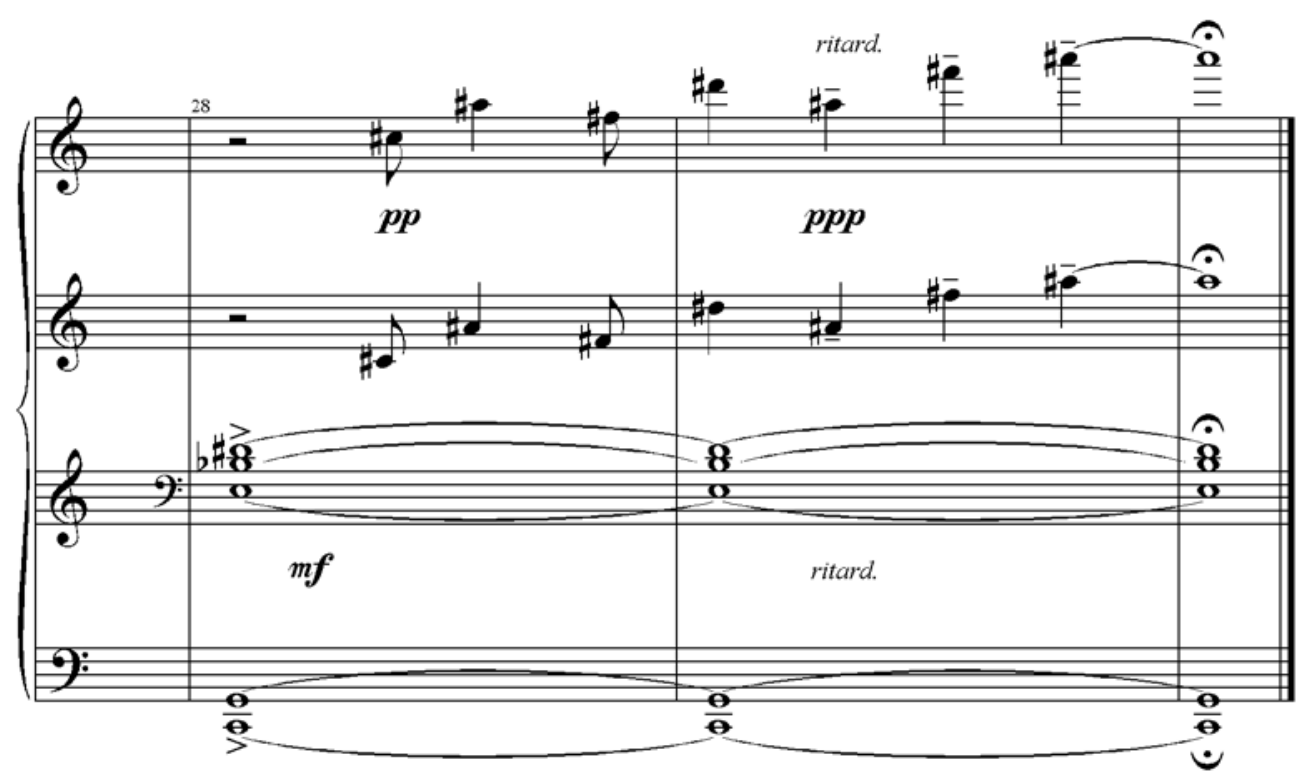

Exemplo 10.2: Prelúdio op. 2 No 9 (c. 28-30). Fonte: Hamond (2005, p.99).

Ao identificar o potencial didático do Prelúdio op.2 № 9 (1998), foi possível observar as seguintes habilidades técnicas desenvolvidas: possibilidade de toque staccato, portato e non legato para enriquecer a sonoridade; passagem escalar em legato (c. 15-16); abertura de m.d. na extensão de 8á; presença de tenuta (c. 3, c. 5-9, c. 10, c. 12, c. 21, c. 29); notas repetidas (c. 4-5; c. 9; c. 17-18); movimento alternado com cruzamento das mãos alternadas para execução de linha melódica (c. 3); acordes de três sons na m.d.; quintas na m.e.; movimento paralelo das mãos (c. 24-30); saltos entre acordes e linha melódica (c. 24-30); notação: leitura em quatro pentagramas (c. 24-30); ornamentação: arpejo com efeito de apojatura (c. 16); pedal direito com troca rítmica para trechos com articulações e troca sincopada nos trechos em legato; possibilidade do uso de pedal tonal para sustentação de notas longas (c. 24-30) e do una corda para enriquecer o timbre (c. 24-30).

\section{Prelúdio № 10}

Este prelúdio é o mais conhecido e mais tocado de toda a produção de Villani-Côrtes, pois é a peça de abertura da suíte Cinco miniaturas brasileiras (1977), para flauta doce e piano, e foi escrita para diversas formações, o que favorece sua divulgação. Naturalmente o andamento de cada versão varia de acordo com as características próprias dos instrumentos para os quais foi transcrita. Na versão para trio de violino, violoncelo e piano, um andamento mais lento valoriza as notas longas dos instrumentos de corda, proporcionando mais expressividade à peça. Porém, as indicações Moderato e M.M. $\eta$ = 58 são adequadas para uma interpretação pianística, favorecendo a manutenção de um caráter fluente, conforme podemos verificar no Exemplo 11.1. As características mais marcantes deste prelúdio são o lirismo, a presença de cromatismo e de uma passagem escalar modal. 


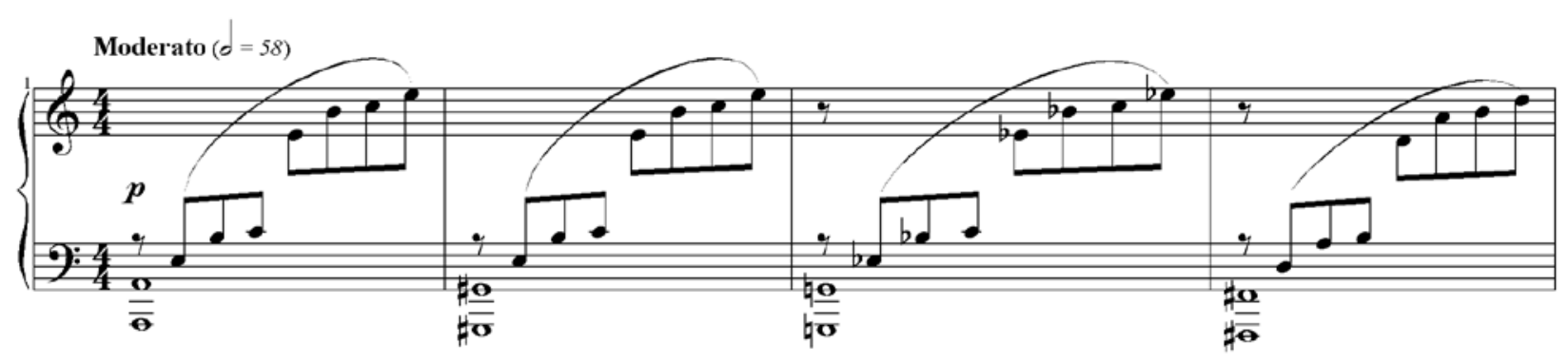

Exemplo 11.1: Prelúdio No 10 (c. 1-4). Fonte: Hamond (2005, p.100).

O intérprete deve ressaltar e equilibrar toda a riqueza de planos sonoros do prelúdio, controlando a dinâmica e o toque. Um material inteiramente novo e inesperado é apresentado: uma sequência descendente de notas em ad lib. e outra ascendente, mais rápida, em movimento alternado das mãos com o caráter etéreo. Este é um momento único, com caráter de improvisação, em que o intérprete tem a liberdade de escolha de como vai conduzir a agógica, conforme observamos no Exemplo 11.2.

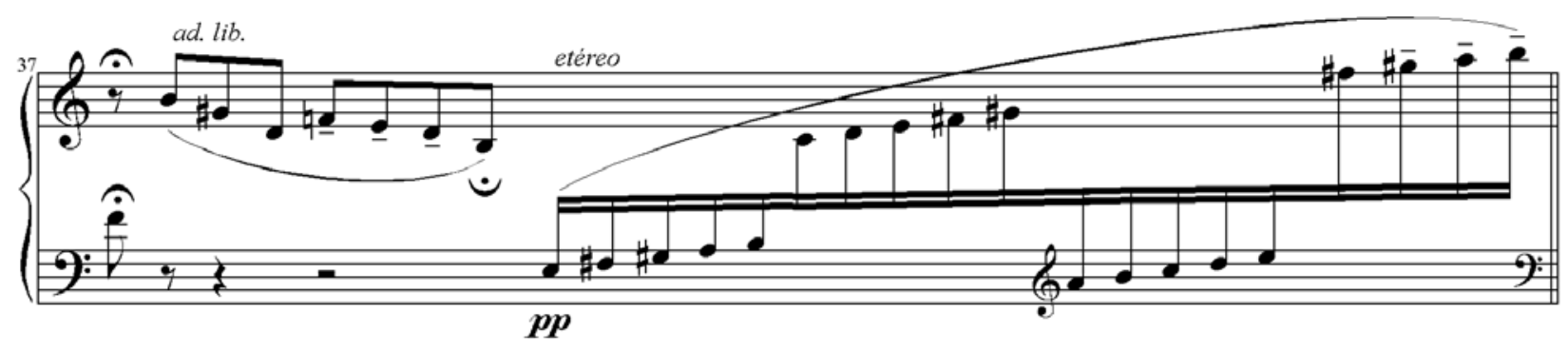

Exemplo 11.2: Prelúdio No 10 (c. 37). Fonte: Hamond (2005, p.102).

A utilização do pedal direito associado com o pedal una corda é uma boa escolha interpretativa para este trecho. $O$ acúmulo de sons proveniente da sequência das notas favorece uma zona de ressonância que retrata exatamente o que o compositor solicita: o caráter etéreo. Apesar de não ser iniciada com nenhum dos temas anteriores, a Coda (c. 53-63) apresenta um material derivado dos mesmos, devido à utilização de arpejos, porém difere em termos melódicos, pois apresenta uma escala modal em lá dórico, um dos únicos momentos em que o material modal é aplicado, conforme mostra o Exemplo 11.3.

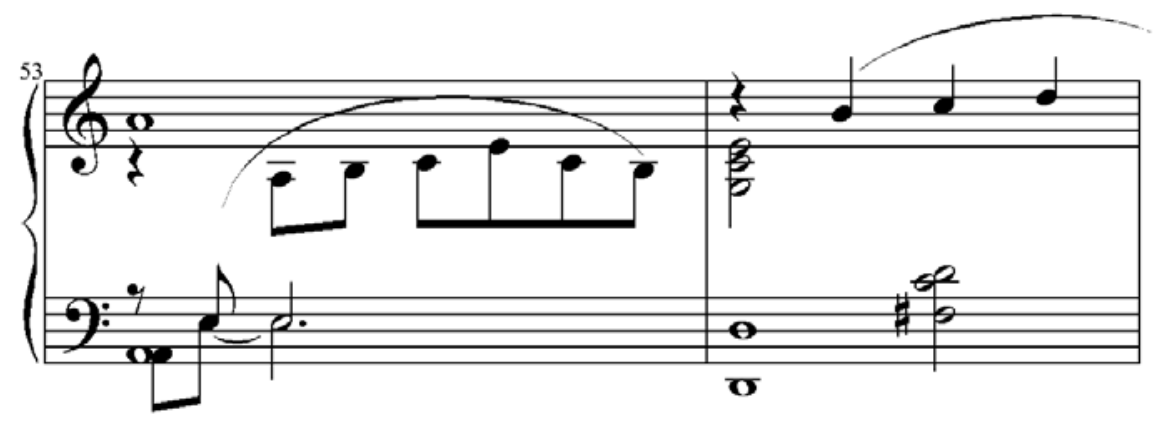

Exemplo 11.3: Prelúdio No 10 (c. 53-54). Fonte: Hamond (2005, p.103). 
Nos últimos compassos, o compositor dá certa liberdade de condução da agógica ao intérprete através da notação com liberdade (c. 60), finalizando a peça.

Ao identificar o potencial didático do Prelúdio № 10, foi possível observar as seguintes habilidades técnicas desenvolvidas: legato em passagem extensa; possibilidade de substituição de dedo; oitavas na m.e. (c. 1-6); arpejos em legato na m.d. (c. 1-6; c. 13-14) e na m.e.; abertura da mão na extensão de $8^{a}$ para m.d. e $10^{a}$ na m.e. por sustentação de notas presas (c. 7-22, c. 39-56); notas presas na m.d. e condução de voz (c. 13-14, c. 20-22, c. 45-46); legato em notas duplas na m.d. (c. 22-23; c. 25-27); acordes de três e quatro sons; acordes com extensão de uma oitava em legato na m.d. (c. 31-36); movimento alternado nas mãos em passagens escalares (c. 37); ornamentação: arpejo com efeito de apojatura (c. 15; c. 39-40; c. 47-49; c. 59); notação: escrita em três pentagramas (c. 47-50); acordes de quatro sons (c. 58); pedal direito com troca sincopada e una corda.

\section{O potencial pedagógico dos onze prelúdios de E. Villani-Côrtes}

A abordagem pedagógica de Uszler (1995) se alinha ao presente trabalho por tratar as potencialidades de um repertório durante o seu estudo técnico-interpretativo, tornando o intérprete consciente dos principais recursos técnicos a serem utilizados até adquirir uma melhor compreensão da obra através da análise musical. Portanto, o papel do professor de piano está em identificar o potencial de uma obra e conscientizar-se de quais são as habilidades técnico-interpretativas necessárias para que um aluno possa se expressar com fluência e clareza através de sua performance. A associação do desenvolvimento técnico-interpretativo com a análise musical da obra é um meio de fazer com que o aluno tenha mais consciência da obra e compreenda melhor uma peça e consiga responder musicalmente, através de seu preparo e vivência, o que ele imaginou expressar.

Podemos dizer que os Prelúdios de Villani-Côrtes trabalham as três áreas propostas por Uszler (1995). Algumas das habilidades estão presentes em todos os prelúdios. Outras áreas são também muito frequentes, mas não ocorrem em todos os prelúdios. A Tab. 6 mostra a incidência das áreas e subáreas de potencial pedagógico para desenvolvimento técnico-interpretativo em cada um dos prelúdios. 


\begin{tabular}{|c|c|c|c|c|c|c|c|c|c|c|c|}
\hline \multirow{2}{*}{ Áneas e subineas } & \multicolumn{11}{|c|}{ Prelátios } \\
\hline & $N^{n} 1$ & $N^{a} 2$ & $N^{2} 3$ & $N^{2} 4$ & $N^{a} 5$ & $N^{m} 6$ & $N^{3} 7$ & $N^{2} 8$ & $\begin{array}{c}N^{29} \\
(1950)\end{array}$ & op. $2 N^{m} g$ & $N^{w} 10$ \\
\hline \multicolumn{12}{|l|}{ 1. Independência } \\
\hline 1.1 & +++ & +++ & +++ & +++ & +++ & +++ & +++ & +++ & +++ & +++ & +++ \\
\hline 1.2 & - & +++ & ++ & +++ & ++ & - & - & ++ & ++ & - & ++ \\
\hline 1.3 & +++ & +++ & +++ & +++ & - & +++ & +++ & +++ & +++ & +++ & +++ \\
\hline 1.4 & ++ & - & + & ++ & ++ & ++ & 0 & +++ & + & - & +++ \\
\hline 1.5 & ++ & ++ & +++ & +++ & ++ & +++ & +++ & +++ & ++ & ++ & ++ \\
\hline \multicolumn{12}{|l|}{ 2. Mobilidade } \\
\hline 2.1 & ++ & + & + & ++ & - & ++ & ++ & - & - & - & + \\
\hline 2.2 & ++ & + & - & - & +++ & - & +++ & - & ++ & - & + \\
\hline 2.3 & +++ & +++ & + & ++ & +++ & ++ & +++ & + & + & + & + \\
\hline \multicolumn{12}{|c|}{ 3. Controle de sonoridade } \\
\hline 3.1 & ++ & +++ & +++ & ++ & +++ & +++ & +++ & ++ & + & +++ & ++ \\
\hline 3.2 & ++ & +++ & +++ & +++ & +++ & +++ & +++ & +++ & ++ & +++ & ++ \\
\hline 3.3 & ++ & ++ & ++ & +++ & + & +++ & ++ & ++ & ++ & + & +++ \\
\hline
\end{tabular}

Tab. 6: Incidência²3 das categorias propostas por Uszler (1995) nos prelúdios para piano de Villani-Côrtes. Fonte: Adaptado de Hamond (2005, p.108).

\section{Conclusão}

Este trabalho veio integrar o Prelúdio № 9 (1956), editado pela Irmãos Vitale Editores (São Paulo) em 1977, aos dez prelúdios da publicação Dez prelúdios e cinco interlúdios (2000). Neste artigo, o Prelúdio No 9 foi incluído cronologicamente após o Prelúdio № 8 e antecedendo o Prelúdio op.2 № 9. Os onze prelúdios podem ser executados isoladamente ou em grupo, em ordem cronológica ou na escolhida pelo intérprete.

O contato com Edmundo Villani-Côrtes, através de entrevistas realizadas e depoimentos, foi imperativo na medida em que possibilitou o conhecimento da sua formação musical, da sua trajetória como músico, de seus pensamentos sobre a música e a vida, da sua produção musical, de suas principais composições para piano e de seu reconhecimento como compositor. As características mais marcantes desses prelúdios são a diversidade e a liberdade da forma musical, a exploração de mudanças harmônicas e a presença de atmosferas introspectivas e contemplativas, na maior parte das vezes.

Os prelúdios são textos musicais que refletem o pensamento do compositor e deixam transparecer o conhecimento e a vivência musical do autor como pianista. As peças são muito bem escritas para o piano, o que torna a obra idiomática para o instrumento. A escrita dos prelúdios é clara e concisa, com um nível de detalhamento que constantemente oferece ao pianista oportunidades de decisões interpretativas, seja através de elementos indicados na partitura, que apresentam diversas possibilidades de execução,

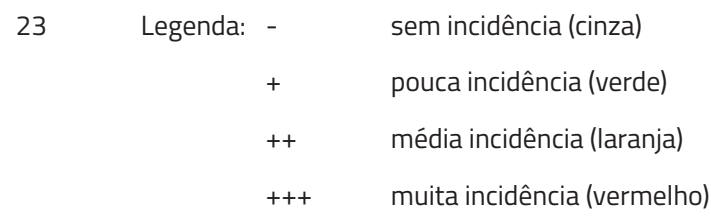


tais como fraseado e sonoridade, seja através de elementos não escritos, convidando o pianista a realizar uma interpretação única e individual de cada obra.

A análise musical dos aspectos interpretativos e técnicos (KOCHEVITSKY, 1967; SCHMALFELDT, 2002; SCHMALFELDT apud CAVAZOTTI; GANDELMANN, 2002) dos prelúdios revelou que esta obra se enquadra nas três áreas de desenvolvimento propostas por Uszler (1995) para o estudo pianístico de nível intermediário. Porém, ressaltamos que os Prelúdios № 1 e $N$ № 7 apresentam características mais próximas às de peças de nível avançado quando comparados aos demais prelúdios. A identificação e a avaliação das habilidades desenvolvidas mostram que esta obra pode ser utilizada como material didático para alunos do nível intermediário do estudo pianístico, auxiliando professores e alunos que buscam escolher um repertório brasileiro ainda pouco conhecido, rico em aspectos técnicos e interpretativos, e representativo da linguagem do compositor. Este repertório, de fácil assimilação e compreensão, pode ser utilizado como material didático para desenvolver habilidades técnicas e interpretativas de alunos do nível intermediário.

\section{REFERÊNCIAS}

ARAUJO FILHO, Alfeu Rodrigues de. Timbres e ritmatas para piano solo de E. VillaniCôrtes: conceito, análise e interpretação pianística. 2011. 408 f. Tese (Doutorado em Música) -Universidade Estadual de Campinas, Campinas, 2011.

BARANCOSKI, Ingrid. A literatura pianística do século XX para o ensino do piano. Per Musi, v. 9, p. 89-113, 2004.

BARONI, Silvio Ricardo. Concerto № 3 para piano e orquestra de Edmundo VillaniCôrtes: uma abordagem técnico-anatômico-pianística. Tese (Pós-Dourorado) Unicamp, Campinas, 2003.

BASTIEN, James W. How to teach piano successfully. Park Ridge: General Words and Music Co.; La Jolla: Neil A. Kjos Jr., 1973.

CARVALHO, Larissa Paggioli de. Edmundo Villani-Côrtes' works for violin and piano: analysis and performance guide. 2016. 219 f. Dissertation (Doctor of Arts) - University of Northern Colorado, Greeley, 2016. Disponível em: https://digscholarship.unco.edu/ dissertations/331/. Acesso em: 30 mar. 2020.

CAVAZOTTI, André; GANDELMAN, Salomea. Uma entrevista com Janet Schmalfeldt. Per Musi: Revista de Performance Musical, Belo Horizonte, v. 5/6, p. 55-67, 2002. Disponível em: http://musica.ufmg.br/permusi/permusi/port/numeros/05_06/ num5_6_cap_04.pdf Acesso em: 21 jul. 2020.

CENTRO CULTURAL SÃO PAULO. Música contemporânea brasileira: Edmundo VillaniCôrtes. Disponível em: http://www.centrocultural.sp.gov.br/musica_contemporanea/ biografia_edmundo.htm. Acesso em: 21 abr. 2012. 
COELHO, Francisco Carlos; DONADIO, Vera Lúcia. Uma conversa com o compositor Edmundo Villani-Côrtes. Revista D’Art, São Paulo, Centro Cultural São Paulo, n. 8, p. 16-23, dez. 2001.

FREITAS, Felipe Gomes de. Concertante para clarineta e orquestra de Edmundo VillaniCôrtes: aspectos técnicos e interpretativos. 2012. 259 f. Dissertação (Mestrado em Música) - Universidade Federal da Bahia, Salvador, 2012.

GANDELMAN, Salomea. 36 compositores brasileiros: obras para piano (1950-1988). Rio de Janeiro: Fundação Nacional de Arte, 1997.

GANDELMAN, Salomea; COHEN, Sara. Cartilha rítmica para piano de Almeida Prado. Rio de Janeiro: [s. n.], 2006.

GIARDINI, Monica. Processos composicionais de Edmundo Villani-Côrtes na sua sinfonia no 1 para orquestra de sopros. 2013. 300 f. Tese (Doutorado em Música) Universidade de São Paulo, São Paulo, 2013.

HAMOND, Luciana Fernandes. Prelúdios para piano solo de Edmundo Villani-Côrtes: um estudo técnico-interpretativo. Dissertação (Mestrado em Música) - Programa de Pós-Graduação em Música, Centro de Letras e Artes, Unirio, Rio de Janeiro, 2005.

HARTMANN, Ernesto. O piano didático de César Guerra-Peixe: uma breve análise dos problemas estilísticos, técnicos e musicais da sua produção de 1942 até 1949. Vórtex, Curitiba, v. 5, n. 3, p. 1-31, 2017.

HOBSON, Ian. Technical development for the intermediate student. In: LYKE, James et al. (org.). Creative piano teaching. 3. ed. Illinois: Stipes Publishing, 1996. p. 324-325.

KOCHEVITSKY, George. The art of piano playing: a cientific approach. Evanston: Summy-Bichard Company, 1967.

KRAUSZ, Luis S. Em conversa: Edmundo Villani-Côrtes. Concerto - Guia Mensal de Música Erudita, São Paulo, ano V, n. 49, mar. 2000.

LIMA, Veronique de Oliveira. Villani-Côrtes por Veronique de Oliveira Lima. Monografia de final de curso da disciplina Música Brasileira II, regida pelo professor Régis Duprat. São Paulo: USP, Escola de Comunicações e Artes, Departamento de Música, dez. 1999.

MACHADO, João Paulo. An analysis and performance guide of three works by brazilian composers featuring the violin. 2017. 183 f. Dissertation (Doctor of Arts) - University of Northern Colorado, Greeley, 2017. Disponível em: https://digscholarship.unco.edu/ dissertations/410/. Acesso em: 30 mar. 2020. 
MATOS, Alexandra L. H. Musicografia. In: COELHO, Francisco Carlos (org.). Música Contemporânea Brasileira: Edmundo Villani-Côrtes. São Paulo: Centro Cultural São Paulo, Discoteca Oneyda Alvarenga, 2006. p. 58-74.

NETO, Cícero Pereira Cordão. Note grouping: uma ferramenta interpretativa como facilitadora do aspecto técnico do trompete no concerto de Edmundo Villani-Côrtes. 2010. 165 f. Dissertação (Mestrado em Música) - Universidade Federal do Estado do Rio de Janeiro, Rio de Janeiro, 2010.

NICOLAU, Thais Lopes. Piano concertos of Edmundo Villani-Cortes. 2013. $182 \mathrm{f}$. Dissertation (Doctor of Arts) - University of Northern Colorado, Greeley, 2013. Disponível em: https://digscholarship.unco.edu/dissertations/220/. Acesso em: 30 mar. 2020.

RINK, John. Análise e (ou?) Performance. Cognição e Artes Musicais/ Cognitions \& Musical Arts, v. 2, n. 1, p. 25-43, 2007. Disponível em: https://hugoribeiro.com.br/ biblioteca-digital/Rink-Analise_performance.pdf. Acesso em: 24 maio 2020.

RODRIGUES, Irailda Eneli Barros Silva. The art song of Edmundo Villani-Côrtes: a performance guide of selected works. Dissertations (Doctor of Musical Arts) University of Kentucky, Virginia, 2014. Disponível em: https://uknowledge.uky.edu/ music_etds/25. Acesso em: 5 mar. 2020.

SANT'ANNA, Affonso R. Edmundo: simplesmente criativo. In: COELHO, Francisco Carlos (org.). Música contemporânea brasileira: Edmundo Villani-Côrtes. São Paulo: Centro Cultural São Paulo, Discoteca Oneyda Alvarenga, 2006. p. 39-49.

SANTOS, Samanta Adriele Neiva dos. Edição crítica do Concerto para Flauta e Orquestra de Edmundo Villani-Côrtes. 2014. 210 f. Dissertação (Mestrado em Música) Universidade Federal da Bahia, Salvador, 2014. Disponível em: https://sucupira.capes. gov.br/sucupira/public/consultas/coleta/trabalhoConclusao/viewTrabalhoConclusao. jsf?popup=true\&id_trabalho $=1884980$.

SCHMALFELDT, Janet. On performance, analysis, and Schubert. Per Musi: Revista de Performance Musical, Belo Horizonte, v. 5/6, p. 38-54, 2002. Disponível em: http:// musica.ufmg.br/permusi/permusi/port/numeros/05_06/num5_6_cap_03.pdf Acesso em: 21 jul. 2020.

SOBREIRO, Andreia Peliccioni. Edmundo Villani-Côrtes: o mestre-educador. Frutal: Prospectiva, 2016

USZLER, Marienne. Technique and the intermediate student. In: USZLER, M.; GORDON, S.; MACH, E. (ed.). The well-tempered keyboard teacher. New York: Schirmer Books, 1995. p. 213-224. 
VILLANI-CÔRTES, Edmundo. Depoimento no curso Seminários de Práticas Interpretativas I. Rio de Janeiro: Unirio, jun./jul. 2003a. (ANEXO 5 de HAMOND, 2005).

VILLANI-CÔRTES, Edmundo. [Entrevista cedida à] Luciana Hamond. São Paulo, 28 e 29 jan. 2004a. (ANEXO 6 de HAMOND, 2005)

VILLANI-CÔRTES, Edmundo. [Entrevista cedida à] Luciana Hamond. Rio de Janeiro, 15 out. 2004b. (ANEXO 7 de HAMOND, 2005)

VILLANI-CÔRTES, Edmundo. Cinco miniaturas brasileiras. Flauta doce e piano. São Paulo: Cultura Musical, 1978. 2 partituras. $14 \mathrm{p}$.

VILLANI-CÔRTES, Edmundo. Dez prelúdios e cinco interlúdios para piano. Piano. São Paulo: Estúdio Dois Produções Culturais e Edições Musicais, 2000. 1 partitura. 52 p.

VILLANI-CÔRTES, Edmundo. Edmundo Villani-Côrtes: 10 Prelúdios e 5 Interlúdios para piano. Rio de Janeiro: Musica Brasilis, 2015.

VILLANI-CÔRTES, Edmundo. Prelúdio No 3. Piano. São Paulo, Rio de Janeiro: Cultura Musical, 1980. 1 partitura. 3 p.

VILLANI-CÔRTES, Edmundo. Prelúdio NNo 4. Piano. São Paulo, Rio de Janeiro: Cultura Musical, 1981. 1 partitura. 3 p.

VILLANI-CÔRTES, Edmundo. Prelúdio No 9. Piano. São Paulo, Rio de Janeiro: Irmãos Vitale, 1977. 1 partitura. $2 \mathrm{p}$.

ZANON, SONIA REGINA. A obra de câmera para contrabaixo acústico de Edmundo Villani-Côrtes: contribuições interpretativas a partir de considerações sobre o idiomatismo do instrumento. 2005. 127 f. Dissertação (Mestrado em Música) Universidade Federal do Estado do Rio de Janeiro, Rio de Janeiro, 2005. 


\section{ANEXO}

\begin{tabular}{|c|c|}
\hline Obras para piano solo & Ano de composiçōo \\
\hline Prelúdios Na.1 a 8 & 1949 \\
\hline Estudo em Nonas & 1950 \\
\hline Estudo Fantástico & 1951 \\
\hline $\begin{array}{l}\text { Série Brasileîra Opus 8: 1. Prelúdio; } 2 \text { Dança; 3. Movimento em 3/4 ;e } \\
\text { 4.Chồro em Forma de Rondó }\end{array}$ & 1957 \\
\hline Prelúdio No. $9(*)$ & 1956 \\
\hline $\begin{array}{l}\text { Suite Infantîl em quatro movimentos: } 1 \text {. A pracinha das crianças; } \\
2 \text { O concurso de papagaios; } 3 \text {. O dia de Sāo Bartolomeu; } \\
\text { e4.Corwersa com o vento }\end{array}$ & 1961 \\
\hline Ponteios No.1, No.2, No.3,e No.4 & 1963 \\
\hline Baīa & 1963 \\
\hline Valsa & 1963 \\
\hline Papagaio Arul & 1966 \\
\hline Timbres Na.1, 23 e4 & 1977 \\
\hline Valsinha de Roda & 1979 \\
\hline Tema com variaçōes & 1979 \\
\hline Charo Uharno & 1979 \\
\hline A Catedral da Sé & 1979 \\
\hline Balada para as Flores & 1989 \\
\hline Pretensioso (choro) & 1981 \\
\hline O Tamborzinho (reminiscênncias infantis) & 1985 \\
\hline Rïtmata No.1 e No.2 & 1985 \\
\hline Ponteio No. 5 & 1986 \\
\hline
\end{tabular}




\begin{tabular}{|c|c|}
\hline Obras para piano solo (continuraço) & Ano de composiço \\
\hline Cançāo de Carolina & 1990 \\
\hline Alma da Natureza & 1991 \\
\hline Casulo & 1991 \\
\hline Rua Almora & 1993 \\
\hline Balada dos 15 mirutos & 1993 \\
\hline Sonata No.1:Lenda, Cantïlena, Corrupio & 1994 \\
\hline Pedrinho's Boogie & 1994 \\
\hline A primeira folha do diário de um Sacī & 1994 \\
\hline Concurso de Papagaios & $1961 / 1995$ \\
\hline Rïtmata No.3 & 1995 (revisāo 2BB8) \\
\hline Chồn do Joāo & 1995 \\
\hline Sonatina: Ingêruso, Tristonho e Agịtado & 1996 \\
\hline Vozes do Agreste & 1996 \\
\hline Poema Brasileiro & 1996 \\
\hline Homem Fillho do Fogo & 1997 \\
\hline Música da Pularia & 1997 \\
\hline O Gabriel chegou (chôro) & 1997 \\
\hline Clara & 1998 \\
\hline Prelúdio No. 9 (B) ou Opus 2 Na.9 & 1998 \\
\hline Prelúdio No. 10 (Prelúdio das Cinco Miniaturas Brasilleiras) & 1998 \\
\hline Os Chorōes da Paulicéia & 1998 \\
\hline O orelha & 1998 \\
\hline Carhoto também tem vez (Chôro para a māo esquerda) & 1999 \\
\hline Chôro Patétíco & 1999 \\
\hline Chôro das Madrugas & 1999 \\
\hline $\begin{array}{l}\text { Álbum de Choros: } 1 . \text { Os chorōes da pauliceia; } 2 \text { O Orelha; 3. Choro do } \\
\text { Joao;4. O Gahriel chegou; 5. Chôro Urbaro; 6. Chôro miniatura; 7. Chôro } \\
\text { das Madrugas; 8. Chôro Patético; 10. Pretensioso }\end{array}$ & 1999 \\
\hline $\begin{array}{l}\text { Álbum Cançōes para piano solo: 1. Valsinha de Roda; } 2 \text { Alma da } \\
\text { Natureza; 3. Rua Aurora;4.Papagaio Azul; 5. Casulo; 6.Chōro das } \\
\text { Madrugas; 7. Balada dos 15 Mirntos; e 8. Cançāo de Carolína }\end{array}$ & 1999 \\
\hline O passarinho da praça da matriz & 1999 \\
\hline Fonte Eterna & 1999 \\
\hline Cînco Interlúdios & 1999 \\
\hline
\end{tabular}




\begin{tabular}{|c|c|}
\hline Obras para piano solo (continuraço) & Ano de composiç̄o \\
\hline Album de 10 Preludios e 5 interiudios & 28BB \\
\hline Adagio & 28B1 \\
\hline Melodia para Luciana & 20B2/22BB6 \\
\hline Valsa Festiva & $28 \mathrm{BB}$ \\
\hline Valsa Saudosa & $28 B 3$ \\
\hline Baile Imaginário & $28 B 9$ \\
\hline Rarucheira (valsa para piarno solo) & 2EBA-2ERS \\
\hline ur & 2885 \\
\hline Sem Nome & $28 \% 5$ \\
\hline Águas Claras - versāo para piano solo. & 2085 \\
\hline Francisco no Chồn & 28B6 \\
\hline A segurnda queda de Jegus - para piaro solo & 2BE6 \\
\hline A pororóca & 28B6 \\
\hline $\begin{array}{l}\text { Cînco Miniaturas Brasileirras versāo piano solo: 1. Prelúdio; 2. Toada; } \\
\text { 3. Choro;4. Cantiga de Ninar; e5. Baiāo }\end{array}$ & 1978/ 2BB6 \\
\hline Rue Ramponeau & 2897 \\
\hline Timbres nr.4-para piano solo, revisāo feita em outuhro de 2897 & 2867 \\
\hline Reflexos & 2867 \\
\hline Rïtmata nr. 3-revisäo para piarno solo & 28BB \\
\hline Anfora & 2801 \\
\hline Valsa das Rosas & 2812 \\
\hline Salve, Salve, Daniel & 28012 \\
\hline Acalanto & 2813 \\
\hline Valsa da Lìi (dedicada a exposa do fillho Ed Cortes) 07/04/2814 & 2814 \\
\hline $\begin{array}{l}\text { Chôro Dengoso (uma singela homenagem ao saudoso e incomparável } \\
\text { Emesto Nazareth) }\end{array}$ & 2014 \\
\hline Chôro do Gugu & 2817 \\
\hline
\end{tabular}




\begin{tabular}{|c|c|}
\hline Ohras para quatio mäos ou para dois pianos & Ano de composiço \\
\hline $\begin{array}{l}\text { Álbum de peças a quatro māos: Belibá (1976), Beiráceas (1978), e } \\
\text { Poranduha (1998) }\end{array}$ & $1976,1978,1998$ \\
\hline Djopoi (piano a quatro mäos) & 2EB2 \\
\hline Os Chorōes da Paulicéia (piano a quatro māos) & 28.83 \\
\hline Dia de descanso - para piano a quatro mäos. & 1974 \\
\hline Caetê Jururê-para dois pianos & 1990 \\
\hline Coraçäo latino-para dois pianos & 2BE6 \\
\hline Chras para ódö & Ano de composiço \\
\hline A Catedral da Sé (prelúdio em estîlo Bachiano) & 1979 \\
\hline Prelúdio e Fuga (versāo orgaristica) & 1983 \\
\hline
\end{tabular}

